
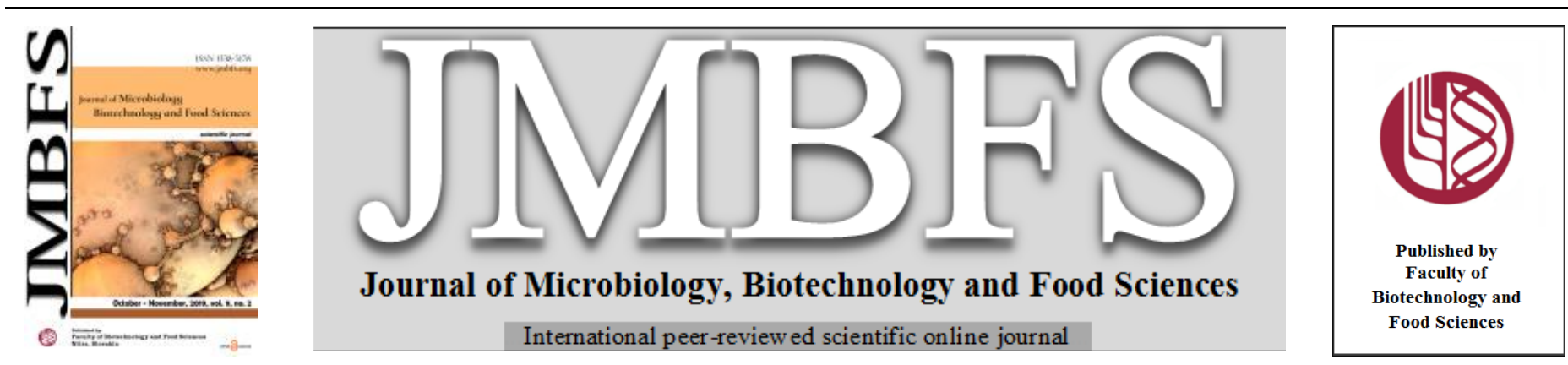

\title{
MICROBIAL PECTINASES: A REVIEW ON MOLECULAR AND BIOTECHNOLOGICAL PERSPECTIVES
}

\section{Saptadip Samanta}

\author{
Address(es): \\ Department of Physiology, Midnapore College, Midnapore, Paschim Medinipur, West Bengal, India, 721101.
}

*Corresponding author: saptadip174@gmail.com

doi: $10.15414 / j m b f s .2019 .9 .2 .248-266$

\section{ARTICLE INFO}

Received 27. 8. 2018

Revised 11. 4. 2019

Accepted 12. 4. 2019

Published 1. 10. 2019

Review

open $\odot$ access

\begin{abstract}
Pectinases are upcoming enzymes in the biotechnological sector. This large group of enzymes involves in break down of pectic polysaccharides, the major component of middle lamella in plant cell wall. The pectin degrading enzymes are categorized according to their mode of action and release of degradative products. Various filamentous fungi, yeast, and bacteria are the common sources of microbial pectinases. Solid state fermentation is more preferable for extracellular microbial pectinases production over the submerged fermentation. A group of genes regulates the expression of pectinolytic enzymes. Mostly, all the enzymes share a common parallel $\beta$ helix topology which consists of a single domain of parallel $\beta$-strands folded into a large right-handed cylinder. These enzymes are ecofriendly tools for industrial applications and being used in various sectors like wine, food, paper industry, waste paper recycling, fruit juice preparation, processing of tea-coffee, animal feed preparation.
\end{abstract}

Keywords: Pectin, pectinases, fermentation, crystal structure, extraction

\section{INTRODUCTION}

Enzymes are extremely efficient biocatalysts to perform all anabolic and catabolic reactions in living systems. They have efficient catalytic activity with definite mode of action, stereospecific binding, eco-friendly nature and low energy expenditure (Bhardwaj et al., 2017). Recently, several microbial enzymes have been extensively used in biotechnological processes as they are eco-friendly and economically sound for the industrial sector. Among the industrially important enzymes, pectinase has great importance in different industrial sectors like fruit and vegetable processing, extraction of vegetable oil, animal feed production, textile, recycling of wastepaper, wine and beverages production, tea and coffee processing (Garg $\boldsymbol{e t}$ al., 2016). Pectinolytic enzymes are present in a complex enzymatic system which are capable to degrade the pectic substances (complex polysaccharide) those are mostly present in higher plants and microorganisms (Jayani et al., 2005; Kittur, et al., 2003). The commercial applications of pectinases were started from 1930s for the production of wines and fruit juices (Ribeiro et al., 2010; Suneetha and Prathyusha, 2011; Oslen, 2013). Applications of pectinases have increased with the passage of time and reached $20 \%$ in the enzyme worldwide market (Hassan and Ali, 2016) Plants, fungi, yeast and bacteria are the natural sources for pectinase production (Ribeiro et al., 2010).

Pectic substances are the versatile structural polysaccharides with high molecular weight and negative charges. They contain long galacturonic acid chains whose varying numbers of carboxyl groups are esterfied with methyl group. They are the major components of middle lamella of plant cell walls that occupies onethird of the dry weight of plant tissue (Voragen et al., 2009; Khan et al., 2013) and appear as cementing and lubricating agents in the cell walls. These components are responsible for giving the texture of fruits and vegetables during growth, and maturation (Alkorta et al., 1998; Caffall and Mohnen, 2009). Beside these, pectin substances are also related to several cellular functions of plants cells like growth and development, defense, seed hydration, ionic bonding, $\mathrm{pH}$ balance, cellular expansion, abscission of leaf and fruit development etc (Lara-Marquez et al., 2011). Pectins have several industrial applications, especially in the food and pharmaceutical sectors. The food industries use these components as gelling agent, nutritional fiber and also for removing of sugars and fats from low-calorie foods (Sakai et al., 1993; Thakur et al., 1997). In the pharmaceutical sectors, they are used as cholesterol reducing agent and also supplemented as lubricant in the preparation used for promoting intestinal movements. Moreover, these polysaccharides are also useful in drug delivery systems due to their low toxicity and durable activity without altering the therapeutic effects of transporting drug (Morris et al., 2010; Schols et al., 2009; Thakur et al., 1997).

The major components of pectic substances are protopectin, pectins and pectic acids. The main chain of pectin contains $\alpha-1,4-\mathrm{D}$-galacturonan which is partially esterified with methyl group. Demethylated pectin is known as pectic acid (pectate) or polygalacturonic acid. Polygalacturonase cleaves the glycosidic linkages of polygalacturonic acid to produce mono-galacturonic acid. The inherent pectinase of plant cells is most important during the ripening of fruits as it starts degradation of middle lamella of plant's cell wall which leads to softening of fruits (Khan et al., 2013). Nowadays, pectinases are the integral part of various biotechnological applications especially in food industries for preparation fruit juices. The present review has focused on pectic substances, pectinolytic enzymes and their characteristics, and industrial applications.

\section{PECTIC SUBSTANCES}

Pectic substances are present in the primary cell wall in the form of calcium pectate and magnesium pectate. These are the major constituents of the middle lamellae which are a thin extracellular adhesive layer in between the walls of adjacent young cells and deposited in the early stages of cell growth to increase strength and support. The dicotyledonous plants contain approximately $35 \%$ pectin, $30 \%$ cellulose, $30 \%$ hemicellulose, and 5\% protein in their primary cell walls while grasses contain $2-10 \%$ pectin (Voragen et al., 2009). Pectin regulates the various properties such as porosity, surface charge, $\mathrm{pH}$, ion balance as well as ion transport in the cell wall (McNeil et $\boldsymbol{a l . , 1 9 8 4 )}$ and it also involves in plant defense by accumulating a broad spectrum anti-microbial component phytoalexin (Jin and West, 1984).

Pectins are the heterogeneous, branched and highly hydrated polysaccharides rich in D-galacturonic acid with negative charges. There are two major constituents of pectins, homogalacturonan (HG) and rhamnogalacturonan (RG); further rhamnogalacturonan is subdivided into rhamnogalacturonan I (RGI) and rhamnogalacturonan II (RGII) (Fig.1). These three major pectic polysaccharides groups contain D-galacturonic acid to a greater or a lesser extent. The Lrhamnose residues may be attached to the main chain through its $\mathrm{C}-1$ and $\mathrm{C}-2$ atoms. Pectin in native form is interlined with other structural polysaccharides and proteins to form the water insoluble substance protopectin in unripe fruits. Synthesis of protopectin starts from UDP-galacturonic acid. The site of synthesis is Golgi system of younger cells whose cell walls are continuously enlarging at the early stages of growth (Karr, 1976). During ripening, the fruit enzymes break the pectin backbone or side chains, resulting in a more soluble molecule (Kashyap et al., 2001). The homogalacturonan (HG) of pectic substances forms 
a gel structure after cross-linking with calcium ions. The gelling properties mainly depends on the interaction between calcium ions and the unesterified carboxyl groups of pectin; moreover, the other determining factors like temperature, $\mathrm{pH}$, types of pectin, degree of esterification and acetylation, presence of sugar and other solutes are also important (Pedrolli et al., 2009).

\section{Homogalacturonan (HG)}

Homogalacturonan is a linear homopolymer of D-galacturonic acid residues attached through $\alpha-(1-4)$ glycosidic bonds and contains as many as 200 galacturonic acid units with a length of about $100 \mathrm{~nm}$ long. The acetyl esterification and methyl esterification of D-galacturonic acid can also be done at C-2 or C-3 position and C-6 position respectively (Fig.1). The methyl esterification determines physical properties of pectin and also sensitive to $\mathrm{Ca}^{2+}$ cross-linking. According to esterification level the molecules are classified into three groups: a) pectin, in which $75 \%$ of its carboxyl groups are methylated; b) pectinic acid which carries less than $75 \%$ methylated carboxyl groups; c) pectic acid or polygalacturonic acid, which does not carry any methyl group at the carboxylic end. (Jayani et al., 2005).

\section{Xylogalacturonan}

Xylogalacturonan (XGA) is a substitute form of homogalacturonan, where $\beta$-Dxylose is present as single unit side chains through $1 \rightarrow 3$ linkages (Fig. 1) and it is commonly present in fruits and seeds (reproductive tissues). A varying degree of xylosidation had been observed in different fruits (25\% in watermelon and $75 \%$ in apple) (Albersheim et al., 1996; Le et al., 2001).

\section{Rhamnogalacturonan I (RG I)}

RG I is a heteropolysaccharide, constructed by repeating disaccharide of rhamnose and galacturonic acid. The repeating disaccharide unit is linked through $(1 \rightarrow 2) \alpha$-L-rhamnose $(1 \rightarrow 4) \alpha$-D-galacturonic acid system. The Galacturonic acid residues of RGI are presumably not methyl esterified, but acetyl group can be present at the position of O-2 and/or O-3 of the GalA residues (Fig. 1). The neutral sugars such as galactose, arabinose, and xylose are linked with galacturonic acid residues and rhamnosyl residues at C-4 carbon as side chains (Caffall and Mohnen, 2009; Willats, 2006).

\section{Rhamnogalacturonan II (RG II)}

RGII is a homogalacturonan chain and mostly present in the plants as conserved structure. It bears four complex side chains which are attached to the galacturonic residues (Willats, 2006). It has the richest diversity of sugars and linkage characteristics. The unusual sugars are apiose, aceric acid (3-C'-carboxy-5deoxy-L-xylse), 2-O-methyl fucose, 2-O-methyl xylose, 3-deoxy-D-manno-2octulosonic acid (KDO), 3-deoxy-D-lyxo-2-heptulosonic acid (DHA) (Fig.1) These side chains are linked to a HG fragment of approximately nine GalA residues, of which some are methyl-esterified. RGII can form borate-diol ester in presence of Boron which can crosslink two HG molecules (Ridley et al., 2001; O'Neill et al., 2001; Ishii and Matsunaga 2001).

\section{Protopectin}

Protopectins are the heterogeneous mixture of pectic substances. They are present as water insoluble component in intact tissue.

\section{PECTINASE PRODUCING ORGANISMS}

Pectinolytic enzymes are abundantly present in nature. They are associated to metabolism of cell wall during cell growth, fruit ripening, abscission, senescence and plant pathogenesis (Gaffe et al., 1997; Dorokhov et al., 1999). Several organisms including bacteria, fungi, yeasts, insects, nematodes, protozoan and plants itself are able to produce these enzymes, but microbial pectinases are intrinsically most important as they are involved in plant-pathogenesis, plantmicrobe interaction, and degradation of dead plant material (Lang and Domenburg, 2000). Pectinases are abundantly produced by saprophytic fungi, plant pathogenic fungi and several bacteria (Gummadi and Panda, 2003; Hasunuma et al., 2003). These microbial pectolytic enzymes show different mode of action and biochemical characteristics (Favela-Torres et al., 2005; Gummadi and Panda, 2003). Bacteria primarily produce alkaline pectinases while, fungi synthesize acid pectinases (Hoondal et al., 2002; Jayani $\boldsymbol{e t}$ al., 2005; Kashyap et al., 2001).

Currently, there are several reports on importance of pectinolytic bacteria. However, the first report on pectin degradation by the bacterium Erwinia sp. was elucidated by Elyrod (1942). Later, it was observed that many bacteria like Erwinia, Yersinia and Klebsiella sp. (Chatterjee et al., 1979), Pseudomonas fluorescens (Zucker et al., 1972) Erwinia carotovora (McMillan et al., 1992; Heikinheimo et al., 1995), Xanthomonas campestris (Liao et al., 1996), Lactobacillus lactis subsp. Cremoris (Karam and Belarbi, 1995), Pseudomonas solanacearum (Schell et al., 1994), Lachnospira pectinoschiza (Cornick et al., 1994) produce inducible extracellular pectinolytic enzymes. Many fungal species are able to degrade pectin by secreting extracellular pectinases. The most common pectinolytic fungi are Aspergillus niger, Aspergillus flavus, Aspergillus terreus, Penicillium chrysogenum, Fusarium moniliforme, Alternaria alternata, Cladosporium cladosporioids and Trichoderma reesei (Saranraj and Naidu, 2014), Alternaria citri, (Isshiki et al., 2001; Juge, 2006), Rhodotorula sp. (Libkind et al., 2004), Phytophthora infestans (Forster, 1988; Sharma et al. 2013b), Saccharomyces cerevisiae (Gainvors et al., 1994; Alimardani-Theuil et al., 2011), Aspergillus niger (Maldonado et al., 1994; Maldonaldo and Saad, 1998), Penicillium frequentans (Kawano et al.,1999), Penicillium occitanis (Hadj et al., 2002), Aspergillus japonicas (Semenova et al., 2003). The genus Aspergillus (Kester and Visser, 1990) and Penicillium (Ikotun, 1984) are commonly used for large scale production of pectinolytic enzymes.

Several studies had indicated that microbial pectinases are produced in multiple forms which differ on their molecular mass and kinetic behaviour (Devi and Rao, 1996; Minjares-Carranco et al., 1997; Sathya et al., 2003). Caprari et al., (1993) reported that polygalacturonases had expressed from one gene or from different genes. They also reported that pathogenic fungus Fusarium moniliforme produces four endo-polygalacturonases from one gene, but the enzymes differ at the extent of glycosylation of the same polypeptide. Another report had shown that polygalacturonases of Aspergillus niger are encoded by a family of diverged genes. (Pedrolli et al., 2009; Coutinho et al., 2003). Pectinases like large group of enzymes are encoded by multigenic families which arise from gene duplication and are linked in tandem (Carroll et al., 2005). The expression of these enzymes have diverged routes (Coutinho et al., 2003). Normally, pectin like polysaccharide cannot enter the cell due to their high molecular weight; but the induction of pectic enzymes in microbial system occurs in alternative way. Initially, low levels of constitutive expression of pectinolytic enzymes takes place before induction. These enzymes appear outside the cell and attack the polymeric substrate leading to release of low molecular products which act as inducers (Fraissinet-Tachet and Fevr, 1996; Cooper, 1983)

de Vries and his coworkers studied the expression of pectinolytic genes in Aspergillus niger (de Vries, 2002); the expression profile of 26 genes of these enzymes was studied under 16 different growth conditions. All genes were expressed in presence of D-galacturonic acid or a metabolite derived from it. Benen et al., (1996) reported that CCCTGA box is present at the promoters of many pectinolytic genes and might be involved in pectinolytic gene expression. Among the 26 pectinolytic genes, 14 genes contain CCCTGA box (de Vries, 2002). According to the expression profile, the pectinolytic genes are clustered into different subset. pgaI, pgaII, pgaB, pgaC, pgaD, pgaE, pelB, pelC, pelF, $p l y A$ and $r h g A$ genes are placed into subset I and they are encoding enzymes for breakdown of pectin main chain. Their expression depends on presence of $\mathrm{D}$ galacturonic acid, polygalacturonate and sugar beet pectin, incubation time and the $\mathrm{pH}$ of the medium. Besides these carbon catabolite repressor protein (CreA) also involves in regulation of expression and elimination of the effects of $\mathrm{CreA}$ is inductive for the gene expression. The other two genes $r g l A$ and $r h g B$ (subset II) and pgaA, pgaX, pelD, pelA, and pmeA (subset III) encode enzymes active on the pectin main chain. The enzymes of subset III appear first and play major role to initiate degradation of pectin. The genes of subset IV (lacA, abnA, abfA, and $a b f B$ ) and subset $\mathrm{V}$ (faeA and $f a e B$ ) are encoding enzymes active on the side chains of pectin (de Vries, 2002). Several fungal pectin lyase genes (pelA, pelB) had been isolated and characterized from Aspergillus niger (Gysler et al., 1990; Kusters-van et al., 1991; Kusters-van et al., 1992), A. oryzae (Kitamoto et al. 2001). Recently, Lima et al., (2017) reported that expression of pectinolytic genes is regulated by catabolic repression. In presence of easily available metabolites, CreA-like protein binds at the promoters of gene ( $5^{\prime}$-SYGGRG-3') to inhibit the gene transcription (Kiesenhofer, 2016).

\section{PRODUCTION OF PECTINOLYTIC ENZYMES}

Microbial pectinase production has been carried out through submerged fermentation (SmF) and solid state fermentation (SSF) by using fungi (Dinu $e$ al., 2007; Castilho et al., 2000; Silva et al., 2002; Pedrolli et al., 2008) and bacteria (Jacob et al.,2008; Klug-Santner et al., 2006; Kashyap et al., 2000; Soriano et al., 2005; Soares et al., 2001). SmF is technically easier than SSF and used for enzyme production from the early stage of biotechnological progress. This process is conducted in stirred tank reactors under aerobic conditions by the use of batch or fed batch systems. Traditionally, SmF was more popular, as the process was very easy to operate and had a greater controlling capacity for the growth parameters like $\mathrm{pH}$, temperature; but, there are some disadvantages: i) large amount of water is essential to operate the fermentation process, ii) continuous agitation must be needed to provide sufficient oxygen which increases the energy consumption as well as operational cost, and iii) produces of huge amount of effluents at post fermentive stage. In addition to, huge capital investment, high energy costs and large infrastructural requirements also make it impractical for industrial purpose in modern age. In contrast to SmF, SSF is the simple technique in which microbial growth occurs on moist solid substrates with negligible free water under aerobic conditions. The solid substrate provides support or sometimes both support and nutrition. 

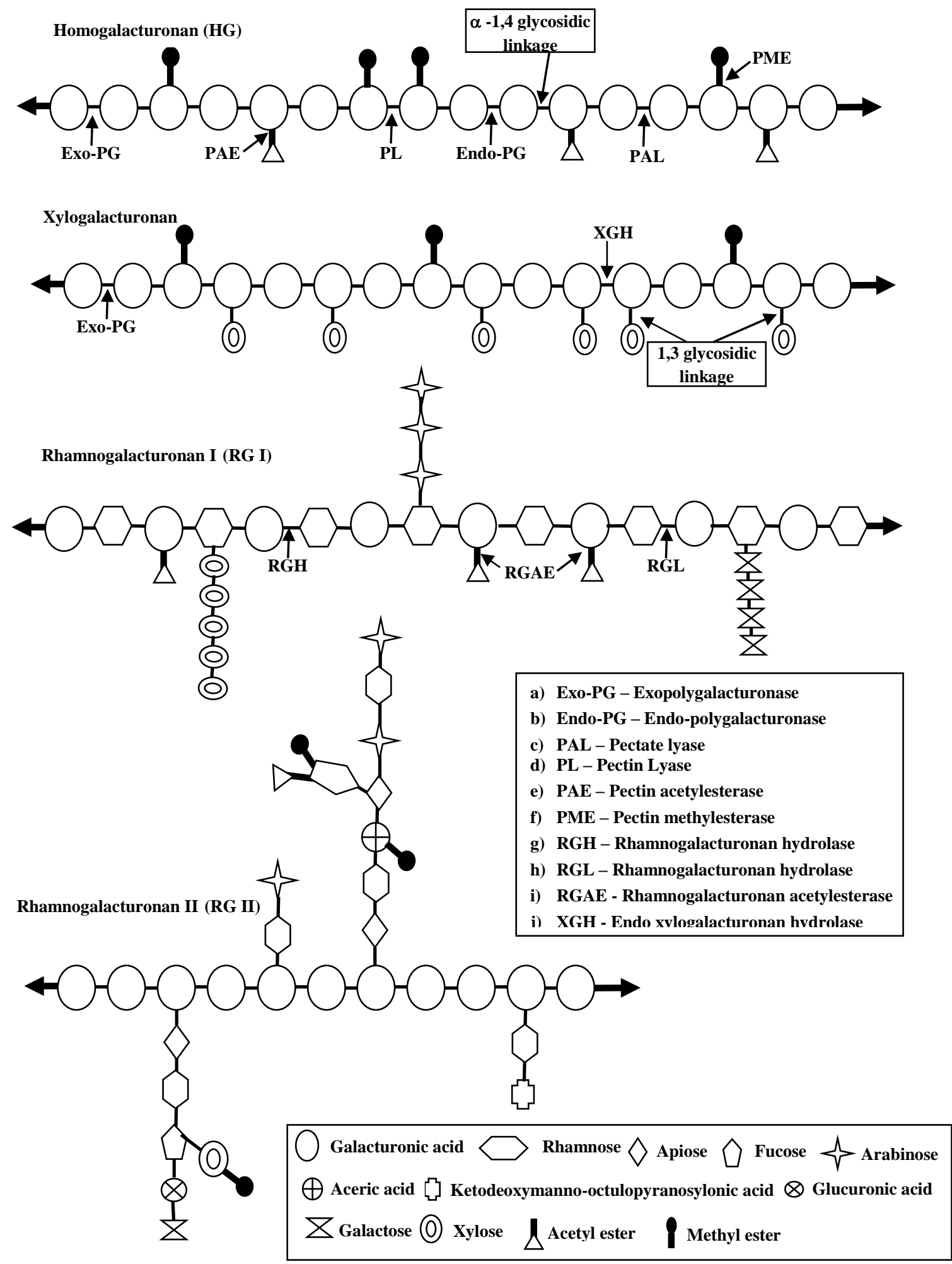

Figure 1The schematic illustration of the basic architecture of pectin substances and the site for attack of pectinases concerned to the degradation of different types of pectin substances (Voragen et al., 2009; Pedrolli et al., 2009).

The major advantages of SSF include low capital investment, lower levels of catabolite repression and end product inhibition, low waste water output, higher productivity, greater enzyme yields and better product recovery (Lonsane $\boldsymbol{e t}$ al., 1985; Hölker and Lenz, 2005).

About $50 \%$ of industrial enzymes come from filamentous fungi and yeast, and they are also widely used in submerged (SmF) and solid state fermentation (SSF) for pectinase production. Filamentous microorganisms are able to grow over the solid substrate. They have potential penetration power at their apical part which makes them more efficient to grow on the low moisture substrates in contrast to non-motile bacteria and yeast (Smith and Aidoo, 1988). Among the filamentous fungi Aspergillus gets most practical importance in SSF for pectinase production in commercial sectors. Several agricultural by products like cassava fibrous waste (Budiatmen and Lonsane, 1987), wheat bran (Ghildyal et al., 1981), apple pomace (Hours et al., 1988) and citrus fruits wastes (Garzon, and Hours, 1992) were used as substrates for the SSF process. Trejo-Hernanadez et al., (1991) had conducted a comparative study to determine the yield of pectinase production from Aspergillus niger and reported that SSF is more productive than SmF.

Mehta et al., (1992) had isolated five strains of Bacillus which were able to produce large amount of polygalacturonase in submerged and semi - solid fermentation. Sittidilokratna et al., (2007) had isolated five strains Erwinia and seven strains of Bacillus for production of pectinases. Erwinia chrysanthemi strain N05 produced highest amount of polygalacturonase, while Bacillus sp. strain N10 gave maximum amount of pectate lyase and pectin lyase. Pectinase and polygalacturonase producing thermophilic filamentous fungal strain Aspergillus fumigatus was isolated by Phutela et al., (2005). Kutateladze $\boldsymbol{e t}$ al., (2009) reported that Penicillium canescens I-85, Aspergillus niger, Trichoderma 
viride Ts-2 were able to produce maximum amount of pectinolytic enzymes in optimized culture conditions.

\section{PECTOLYTIC ENZYMES}

Pectinolytic enzymes or pectic enzymes or pectinases belong to hydrolases, lyases and esterases family which cleave the pectic substances through depolymerization and deesterification reactions. Table 1 shows the classification of different pectolytic enzymes.

Table 1 Different types of pectinases, their mode of action and reaction products (adopted from Jayani et al., 2005; Garg et al., 2016).

\begin{tabular}{|c|c|c|c|c|c|c|}
\hline Types of enzyme & Common name & E.C. No. & Substrate & Mode of action & Product & Assay methods \\
\hline \multicolumn{7}{|l|}{ De-esterifying enzymes } \\
\hline $\begin{array}{l}\text { Polymethyl galacturonate } \\
\text { esterase (PMGE) }\end{array}$ & Pectin esterase & 3.1 .1 .11 & Pectin & $\begin{array}{l}\text { Hydrolysis } \\
\text { Random attack to } \\
\text { cleave the methyl } \\
\text { ester group of } \\
\text { galacturonate unit }\end{array}$ & $\begin{array}{l}\text { Pectic acid + } \\
\text { methanol }\end{array}$ & $\begin{array}{l}\text { Estimation of } \\
\text { methanol by } \\
\text { spectrometric } \\
\text { method. }\end{array}$ \\
\hline Pectin acetyl esterase & Pectin esterase & 3.1 .1 .6 & Pectin & $\begin{array}{l}\text { Hydrolysis } \\
\text { Random attack to } \\
\text { cleave the acetyl } \\
\text { ester group of } \\
\text { galacturonate unit }\end{array}$ & $\begin{array}{lll}\begin{array}{l}\text { Pectic } \\
\text { ethanol }\end{array} & \text { acid }+\end{array}$ & $\begin{array}{l}\text { Estimation of } \\
\text { pNP } \\
\text { spectrophotometr } \\
\text { ically by using } \\
\text { pNP-acetyl } \\
\text { substrate. }\end{array}$ \\
\hline \multicolumn{7}{|l|}{ De-polymerising enzymes } \\
\hline \multicolumn{7}{|l|}{ (a) Hydrolases } \\
\hline \multicolumn{7}{|c|}{ (i) Polygalacturonases (PG)—Catalyzes the hydrolytic reaction of $\alpha-1,4$-glycosidic bond in pectic acid } \\
\hline $\begin{array}{l}\text { Endopolygalacturonase } \\
\text { (Endo-PG) }\end{array}$ & Polygalacturonase & 3.2 .1 .15 & Pectic acid & $\begin{array}{l}\text { Hydrolysis } \\
\text { Randomly } \\
\text { attacks the } \\
\text { pectic acid }\end{array}$ & $\begin{array}{l}\text { Oligogalacturonat } \\
\text { es }\end{array}$ & \multirow{3}{*}{$\begin{array}{l}\text { Estimation of } \\
\text { reducing sugar by } \\
\text { using } 3,5- \\
\text { dinitrosalicylate } \\
\text { reagent or } \\
\text { arsenomolybdate } \\
\text {-copper reagent. }\end{array}$} \\
\hline $\begin{array}{l}\text { Exopolygalacturonase } \\
\text { (Exo-PG1) }\end{array}$ & Polygalacturonase & 3.2 .1 .67 & Pectic acid & $\begin{array}{l}\text { Hydrolysis } \\
\text { Starts bond } \\
\text { breakdown from } \\
\text { the terminal site } \\
\text { of the non- } \\
\text { reducing end of } \\
\text { polygalacturonic } \\
\text { acid }\end{array}$ & $\begin{array}{l}\text { Mono- } \\
\text { galacturonates }\end{array}$ & \\
\hline $\begin{array}{ll}\text { Exopolygalacturonase } & 2 \\
\text { (Exo-PG2) } & \\
\text { (Exopolygalacturonan- } \\
\text { digalacturono } \\
\text { hydrolase) }\end{array}$ & Polygalacturonase & 3.2 .1 .82 & Pectate & $\begin{array}{l}\text { Hydrolysis } \\
\text { Penultimate } \\
\text { attack }\end{array}$ & Di-galacturonates & \\
\hline \multicolumn{7}{|c|}{ (ii) Polymethylgalacturonases (PMG) —Catalyses the hydrolytic reaction of $\alpha-1,4$-glycosidic bond in pectin. } \\
\hline Endo-PMG & Pectin hydrolase & & Pectin & Random attack & $\begin{array}{l}\text { Oligo methyl- } \\
\text { galacturonates }\end{array}$ & $\begin{array}{l}\text { The product is } \\
\text { analyzed by }\end{array}$ \\
\hline Exo-PMG & Pectin hydrolase & & Pectin & $\begin{array}{l}\text { Attacks the bond } \\
\text { from the terminal } \\
\text { site of the non- } \\
\text { reducing end of } \\
\text { pectin }\end{array}$ & $\begin{array}{l}\text { Methyl mono- } \\
\text { galacturonate }\end{array}$ & $\begin{array}{l}\text { paper } \\
\text { chromatopraphy }\end{array}$ \\
\hline
\end{tabular}

(b) Lyases

(i) Polygalacturonate Lyase (PGL) - Catalyses the breakdown of $\alpha$-1,4-glycosidic bond in pectic acid by trans-elimination and forms unsaturated galacturonates.

\begin{tabular}{|c|c|c|c|c|c|c|}
\hline $\begin{array}{l}\text { Poly-(1-4)- } \alpha \text {-D- } \\
\text { galactosiduronate } \\
\text { lyase (Endo-PGL) }\end{array}$ & Pectate lyase & 4.2 .2 .2 & $\begin{array}{l}\text { Pectic acid } \\
\text { /Pectate }\end{array}$ & $\begin{array}{l}\text { Transelimination } \\
\text { Random cleavage }\end{array}$ & $\begin{array}{l}\text { Unsaturated oligo- } \\
\text { galacturonates }\end{array}$ & $\begin{array}{l}\text { Double bonds of } \\
\text { the unsaturated } \\
\text { products at the } \\
\text { non-reducing }\end{array}$ \\
\hline $\begin{array}{l}\text { Poly-(1-4)- } \alpha-\mathrm{D}- \\
\text { galactosiduronate } \\
\text { exolyase (Exo-PGL) }\end{array}$ & Pectate lyase & 4.2 .2 .9 & $\begin{array}{l}\text { Pectic acid } \\
\text { /Pectate }\end{array}$ & $\begin{array}{l}\text { Transelimination } \\
\text { Cleavage of } \\
\text { penultimate } \\
\text { bonds } \\
\text { from non- } \\
\text { reducing end }\end{array}$ & $\begin{array}{l}\text { Unsaturated di- } \\
\text { galacturonates }\end{array}$ & $\begin{array}{lr}\text { ends can } & \text { be } \\
\text { detected } & \text { to } \\
\text { measure } & \text { the } \\
\text { increase } & \text { in } \\
\text { absorbance } & \text { at } \\
235 & \mathrm{~nm} .\end{array}$ \\
\hline $\begin{array}{l}\text { Oligo-D-galactosiduronate } \\
\text { lyase }\end{array}$ & Pectate lyase & 4.2.2.6 & $\begin{array}{l}\text { Oligo- } \\
\text { galacturonate }\end{array}$ & $\begin{array}{l}\text { Terminal } \\
\text { cleavage }\end{array}$ & $\begin{array}{l}\text { Unsaturated mono- } \\
\text { galacturonates }\end{array}$ & $\begin{array}{l}\text { Estimation of } \\
\text { reducing group } \\
\text { can also be } \\
\text { possible by using } \\
\text { 3,5- } \\
\text { dinitrosalicylate } \\
\text { reagent or } \\
\text { arsenomolybdate } \\
\text {-copper reagent. }\end{array}$ \\
\hline
\end{tabular}

(ii) Polymethylgalacturonate Lyase (PMGL) — Catalyses breakdown of $\alpha$-1,4-glycosidic bond in pectin by trans-elimination and forms unsaturated methyl galacturonates from the non-reducing end.

\begin{tabular}{llllll}
$\begin{array}{l}\text { Endopolymethyl-D- } \\
\text { galactosiduronate } \\
\text { lyase (Endo -PMGL) }\end{array}$ & Pectin lyase & 4.2 .2 .10 & Pectin & $\begin{array}{l}\text { Transelimination } \\
\text { Random attack }\end{array}$ & $\begin{array}{l}\text { Unsaturated } \\
\text { methyl } \\
\text { galacturonates }\end{array}$ \\
\hline $\begin{array}{l}\text { Exopolymethyl-D- } \\
\text { galactosiduronate } \\
\text { lyase (Exo-PMGL) }\end{array}$ & Pectin lyase & & Pectin & Terminal attack & $\begin{array}{l}\text { Unsaturated } \\
\text { methyl } \\
\text { galacturonates }\end{array}$ \\
\hline
\end{tabular}




\section{Act on Rhamnogalacturonan}

$\begin{array}{llllll}\text { Rhamnogalacturonan } & \text { Rhamnogalacturonase } & 3.2 .1 .171 ; & \text { Rhamnogalact } & \text { Hydrolysis } & \text { Oligogalacturonat } \\ \text { hydrolases } & \mathrm{s} & 3.2 .1 .173 ; & \text { uronan chain } & & \text { es } \\ & & 3.2 .1 .174 & & \end{array}$

3.2.1.174

$\begin{array}{lll}\text { Rhamnogalacturonan } & 4.2 .2 .23 ; & \text { Rhamnogalact } \\ \text { lyases } & 4.2 .2 .24 ; & \text { uronan chain }\end{array}$

4.2.2.24; uronan chain

Act through
random
transelimination

transelimination $\begin{array}{ll}\text { Unsaturated } & \text {-copper reagent. } \\ \text { galacturonate at the unsaturated } \\ \text { nonreducing end products at the } \\ \text { of one oligomer }\end{array}$ and rhamnose as a ends can be reducing end detected to residue of second measure the oligomer increase in absorbance at $235 \mathrm{~nm}$.

\section{Rhamnogalacturonan}

rhamnohydrolases (RGRH)

\section{2 .1 .40}

Rhamnogalact
uronan chain

d

Estimation of

Rhamnose by

$\begin{array}{lrl}\text { Hydrolysis } & \text { from } & \text { Rhamnose from } \\ \text { nonreducing } & \text { end } & \text { terminal end } \\ \text { through } & \text { exo- } & \end{array}$
acting fashion

Estimation of

reducing sugar by

using $3,5-$

dinitrosalicylate

reagent or

arsenomolybdate

-copper reagent.

using cysteine

hydrochloride and sulfuric acid reagent.

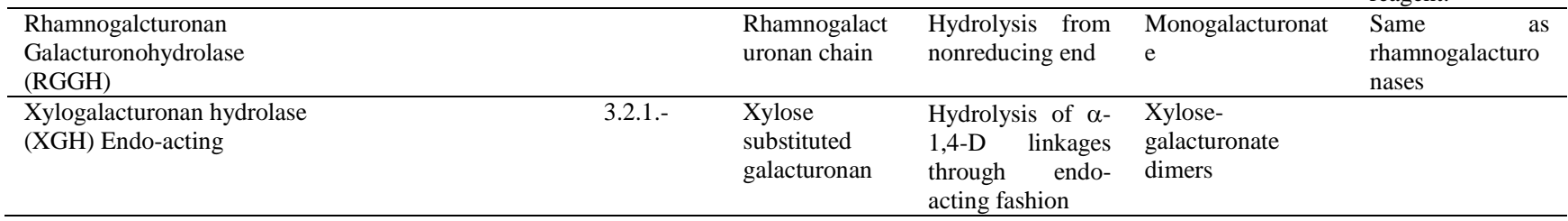

\section{Protopectinases}

Protopectinases were originally named by Brinton et al., (1927).which cleave insoluble protopectin into highly polymerized soluble pectin (Jayani $\boldsymbol{e t} \boldsymbol{a l}$. 2005). The activity of protopectinase is determined by estimating the amount of pectin related material released from protopectin through carbazole sulphuric acid method. They are divided into two groups: type A: which reacts with the polygalacturonic acid region of protopectin, and type B: which reacts with the polysaccharide chains that is present in between polygalacturonic acid chain and cell wall constituents (Sakai et al., 1993). Microbial A type protopectinase is divided into different subtypes like protopectinase $\mathrm{L}, \mathrm{S}$ and $\mathrm{F}$. Their molecular weight is $30 \mathrm{kD}$; but F-type protopectinase is an acidic protein, while $\mathrm{S}$ and $\mathrm{L}$ type protopectinases are basic proteins. On the other side, type $\mathrm{B}$ protopectinase is classified into $\mathrm{B}, \mathrm{C}$ and $\mathrm{T}$. The molecular weights of protopectinase $\mathrm{B}, \mathrm{C}$ and $\mathrm{T}$ are 45,30 , and $55 \mathrm{kD}$ respectively. The isoelectric point $(\mathrm{pI})$ of protopectinase $\mathrm{B}$ and $\mathrm{C}$ are approximately 9.0 and protopectinase T has 8.1 (Hassan and Ali, 2016).

\section{Pectin Methyl Esterases (PME) (EC 3.1.1.11)}

Pectin methyl esterase or pectin esterase releases methyl group from 6-carboxyl group of galacturonic acid of pectin backbone and ultimately generates a nonmethylaed galacturonate unit (pectic acid) and methanol (Cosgrove, 1997). It acts before the activity of polygalacturonases and pectate lyases because they only act on non-esterified substrates (Kashyap et al., 2001). Pectin methyl esterase is primarily produced by plants such as banana, citrus fruits and tomato and also by bacteria and fungi (Hasunuma et al., 2003).

\section{Pectin Acetyl Esterases (PAE) (EC 3.1.1.1)}

It is very similar to pectin methyl esterase and hydrolytically cleaves the esterified acetyl group of pectin, produces pectic acid and acetate (Shevchik $\boldsymbol{e t}$ al., 1997).

\section{Polymethyl galacturonases (PMG)}

Basically, this enzyme belongs to hydrolase which hydrolytically cleaves the $\alpha$ 1,4-glycosidic bonds in highly esterified pectin backbone, forming 6-methyl-Dgalacturonate (Jayani $\boldsymbol{e t} \boldsymbol{a l . ,}$ 2005). The activity of the enzyme is measured by estimating the reducing sugars or by measuring the loss of viscosity of the substrate. Several species of Aspergillus and Penicillium are the rich sources of PMG.

\section{Polygalacturonases (PG)}

Polygalacturonase is under glycosyl-hydrolases family 28 which catalyzes $\alpha-1,4$ glycosidic linkages in polygalacturonates (pectates), producing D-galacturonate (Suneetha and Prathyusha, 2011; Coutinho and Henrissat, 1999).
Polygalacturonases are mostly used in food industry for the preparation of jams, jellies, fruit juices and mixing of soluble dietary fiber (Sharma et al., 2013a) Polymethylgalacturonases and polygalacturonases (PMG and PG) can act in an endo-acting or exo-acting mode. Endo-acting PG mostly prefers non-esterified substrate and the activity decreases along with degree of methyl-esterification (Parenicová et al., 2000). Endo-PG (EC 3.2.1.15) and endo-PMG can act through random cleavage of substrate while, exo-acting PG (EC 3.2.1.67) and PMG starts hydrolysis of substrate from non-reducing end, produces monogalacturonate or digalacturonate in few cases (Rombouts et al., 1980; Kashyap et al., 2001). Fungi, bacteria and yeast are the major sources of endo PGs (Sharma et al., 2012) and the activity of PG can be determined as the same process of PMG.

\section{Polygalacturonate lyase (PGL)}

Pectate lyase is a $\mathrm{Ca}^{2+}$ dependent enzyme and cleaves glycosidic linkages through transelimination reaction. $\mathrm{Ca}^{2+}$ chelating agent like EDTA enables to inhibit the activity of PGL. Endo-PGL (EC 4.2.2.2) attacks $\alpha-1,4$-glycosidic linkages of the substrate in random fashion, and exo-PGL (EC 4.2.2.9) starts substrate breakdown from non-reducing end by cleaving $\alpha-1,4$-glycosidic linkages through sequential manner (Rombouts et al., 1980; Pitt, 1988). Microorganisms are the only sources of PGLs and produce $\Delta 4: 5$ unsaturated oligogalacturonates from substrate after enzymatic breakdon. PGLs show optimum $\mathrm{pH}$ in the region 6-10, which is much higher than other pectinases (Truong et al., 2001; Dixit et al., 2004).

\section{Pectin Lyases (PL)}

Pectin lyases (EC 4.2.2.10) are mainly endo-attacking and not strictly $\mathrm{Ca}^{2+}$ dependent but prefer cations for their action (Pedrolli et al., 2009). They degrade highly esterified pectic substances in a random manner, produce $\Delta$ 4:5 unsaturated oligomethylgalacturonates through transelimination reaction. Pectin lyase A from Aspergillus niger produces mono-, di-, tri- and tetragalacturonates and also generates unsaturated di-, tri- and tetragalacturonates from methyloligogalacturonates but not the monogalacturonates (van Alebeek $\boldsymbol{e t}$ al. 2002). Fungal lyses are active in acidic and neutral medium; however, bacterial lyses show activity in alkaline medium.

\section{Rhamnogalacturonan Rhamnohydrolases (RGRH)}

Rhamnogalacturonan rhamnohydrolases are the group of enzymes comprising to RG rhamnohydrolase, rhamnogalacturonan $\alpha$-L-rhamnopyranohydrolase or $\alpha$-Lrhamnosidase (EC 3.2.1.40). They belong to glycosyl-hydrolase families 28, 78 and 106 (Coutinho and Henrissat, 1999). These enzyme hydrolyze rhamnogalacturonan chain at nonreducing end through exo-acting fashion and liberate terminal rhamnosyl residues attached $(1 \rightarrow 4)$ to $\alpha$ - galacturonosyl residues (Mutter et al., 1994). 


\section{Rhamnogalcturonan Galacturonohydrolase (RGGH)}

RG galacturonohydrolase is a glycosyl hydrolase family 28 (Coutinho and Henrissat, 1999) which hydrolyses rhamnogalacturonan chain at nonreducing end producing monogalacturonate (Mutter et al., 1998).

\section{Rhamnogalacturonan Hydrolases (RGH)}

RG hydrolase randomly cleaves the $\alpha-\mathrm{D}-1,4-\mathrm{GalA}-\alpha-\mathrm{L}-1,2-\mathrm{Rh}$ bond of rhamnogalacturonan chain, leaving $\mathrm{Rha}$ at the non-reducing end. The products are oligogalacturonates (Mutter et al., 1998; Schols et al., 1990).

\section{Rhamnogalacturonan Lyases (RGL)}

These enzymes belong to polysaccharides lyase families 4 and 11 (Coutinho and Henrissat, 1999). RG lyases are very similar to pectin lyases. They also act through random transelimination of the rhamnose-galcturonate linkage of rhamno-galacturonan chain. This enzyme cleaves the $\alpha$-L-1,2-Rha- $\alpha \mathrm{D}-1,4-\mathrm{GalA}$ backbone leaving a 4-deoxy- $\beta$-L-threo-hex-4-enepyranosyluronic acid (unsaturated GalA) group at the non-reducing end. The hydrolyzing products are unsaturated galacturonate at nonreducing end of one oligomer and rhamnose as a reducing end residue of second oligomer (Mutter et al., 1996; Voragen et al., 2009).

\section{Rhamnogalacturonan Acetylesterase}

RG acetylesterase is under the carbohydrate esterase family 12 (Coutinho and Henrissat, 1999) which removes acetyl groups from rhamnogalacturonan chain.

\section{Xylogalacturonan hydrolase}

Xylogalacturonase also belongs to glycosyl-hydrolase family 28 (Coutinho and Henrissat, 1999). It acts on the $\alpha-1,4-D$ linkages of xylose-substituted galacturonan moieties in xylogalacturonan chain to produce xylose-galacturonate dimers after hydrolytic cleavage of glycosidic linkages

\section{PHYSICO-CHEMICAL CHARACTERIZATION OF PECTINOLYTIC ENZYMES}

The efficacy of microbial enzymes depends on the various parameters like $\mathrm{pH}$ temperature, incubation time, agitation, concentration of enzyme and substrate, presence of metal ion and inhibitors, viscosity of the medium, presence of emulsifier, and interaction between enzyme and substrate interface. Many researchers had described the characteristics, biochemical properties and mechanisms of action of microbial pectic enzymes and Table 2 shows some physicochemical properties of pectic enzymes produced by different microorganisms. The optimum $\mathrm{pH}$ and temperature of pectinases from different sources vary between $3.5-11$ and $40-75{ }^{\circ} \mathrm{C}$ respectively (Gummadi and Panda, 2003; Kashyap et al., 2001).

Table 2 Physicochemical properties of some pectinases and their sources.

\begin{tabular}{|c|c|c|c|c|c|c|c|}
\hline \multirow[t]{2}{*}{ Types of enzyme } & \multicolumn{2}{|l|}{ Source } & \multirow{2}{*}{$\begin{array}{l}\text { Types of } \\
\text { enzyme }\end{array}$} & \multirow{2}{*}{$\begin{array}{l}\text { Molecular } \\
\text { mass }(k D)\end{array}$} & \multirow{2}{*}{$\begin{array}{l}\text { Optimum } \\
\text { pH }\end{array}$} & \multirow{2}{*}{$\begin{array}{l}\text { Optimum } \\
\text { temperature } \\
\left({ }^{\circ} \mathrm{C}\right)\end{array}$} & \multirow[t]{2}{*}{ References } \\
\hline & Fungi & Bacteria & & & & & \\
\hline \multirow[t]{5}{*}{ Polygalacturonases } & $\begin{array}{l}\text { Aspergillus } \\
\text { japonicus, } \\
\text { Aspergillus } \\
\text { niger, } \\
\text { Aspergillus } \\
\text { awamori, } \\
\text { Saccharomyces } \\
\text { cerevisiae }\end{array}$ & & Endo & $38-63$ & $3.0-5.5$ & $30-45$ & $\begin{array}{l}\text { Hasunuma et al., } \\
\text { 2003; Singh and } \\
\text { Rao, 2002; Nagai } \text { et } \\
\text { al., 2000; Corredig } \\
\text { et al., 2000 }\end{array}$ \\
\hline & $\begin{array}{l}\text { Penicillium } \\
\text { frequentans }\end{array}$ & & Exo & 63 & 5.0 & 50 & Favey et al., 1992 \\
\hline & $\begin{array}{l}\text { Fusarium } \\
\text { oxysporum }\end{array}$ & & Exo & 38 & 11.0 & 69 & $\begin{array}{ll}\text { Pietro } & \text { and } \\
\text { Roncero, 1996 }\end{array}$ \\
\hline & & $\begin{array}{ll}\text { Bacillus } & s p \\
\text { KSM-P410 } & \end{array}$ & Exo & 63 & 7.0 & 60 & $\begin{array}{l}\text { Koboyashi et al., } \\
2001\end{array}$ \\
\hline & & $\begin{array}{l}\text { Bacillus } \\
\text { licheniformis }\end{array}$ & Exo & 38 & 11.0 & 69 & Singh et al., 1999 \\
\hline \multirow[t]{2}{*}{ Lyases } & $\begin{array}{ll}\text { Aspergillus } & \\
\text { japonicus, } & \\
\text { Penicillium } & \\
\text { italicum, } & \\
\text { Penicillium } & \\
\text { adametzii, } & P \\
\text { citrinum, } & P \\
\text { janthinellum } & \\
\end{array}$ & & PMGL & & $6.0-8.0$ & $40-60$ & $\begin{array}{l}\text { Alana et al., 1990; } \\
\text { Sapunova et al., } \\
\text { 1995; Dinnella et } \\
\text { al., 1994 }\end{array}$ \\
\hline & & $\begin{array}{l}\text { Erwinia } \\
\text { carotovora, } \\
\text { Bacillus } \\
\text { macerans, } \\
\text { Yersinia } \\
\text { enterocolitica, } \\
\text { Bacillus sp. } \\
\text { TS4 }\end{array}$ & PGL & $36-55$ & $8.0-11.0$ & $50-70$ & $\begin{array}{l}\text { Miyazaki, 1991; } \\
\text { Fayyaz et al., 1993; } \\
\text { Singh et al., 1999; } \\
\text { Takao et al., 2000; } \\
\text { Kashyap et al., } \\
2000\end{array}$ \\
\hline \multirow[t]{2}{*}{ Pectinesterases } & & $\begin{array}{l}\text { Erwinia } \\
\text { chrysanthemi } \\
\text { B341, E. } \\
\text { chrysanthemi } \\
3604\end{array}$ & & 37 & $5.0-9.0$ & 50 & $\begin{array}{l}\text { Pitkänen et al., } \\
\text { 1992; Maldonaldo } \\
\text { and Saad, } 1998\end{array}$ \\
\hline & $\begin{array}{l}\text { Aspergillus } \\
\text { japonicus }\end{array}$ & & & 47 & $4.0-5.5$ & & $\begin{array}{l}\text { Hasunuma et al., } \\
2003\end{array}$ \\
\hline
\end{tabular}

Polygalacturonases (PG)

Polygalacturonases (endo PGs and Exo PGs) of different microbial sources show different physicochemical properties. Normally, the optimum $\mathrm{pH}$ and temperature of $\mathrm{PG}$ range from $3.5-5.5$ and $30-50{ }^{\circ} \mathrm{C}$ respectively. While, PG obtained from B. licheniformis and F.oxysporum f. sp. Lycopersci is active in highly alkaline $\mathrm{pH}$ (optimum $\mathrm{pH} 11$ ). The endo PGs exist in different forms; their molecular weights, $\mathrm{pI}$, optimum $\mathrm{pH}$ and temperature vary in between $30-80 \mathrm{kD}$, $3.8-7.6,2.5-6.0$ and $30-50{ }^{\circ} \mathrm{C}$ respectively (Singh and Appu-Rao, 1989; Takao et al., 2000). The endo PGs are the inverting glycosidases which invert the anomeric structure of the products and rapid loss of viscosity of substrate has also been observed during hydrolyzing reaction. Similarly, Exo PGs of A. niger, Erwinia sp. and some plants (peaches, citrus and apples) have shown the molecular weight and $\mathrm{pI}$ in between $30-50 \mathrm{kD}$ and 4.0-6.0 respectively (Alonso et al., 2003; Pathak and Sanwal, 1998). The mode of action of fungal exo-PGs and bacterial exo-PG are quite different. Fungal exo-PGs give monogalacturonic acid as the end product from non reducing end of polygalacturonic acid; whereas, bacterial exo-PG produces di-galacturonate from the same reaction (Sakai $\boldsymbol{e t}$ al., 1993). 
The mechanism of hydrolytic reaction has been done through a general acid base catalysis system. During reaction, acid catalyst donates a proton to the glycosidic oxygen, and then the base part starts the nucleophilic attack on the anomeric carbon of the galacturonate moiety (Shimizu et al., 2002). The study of sitedirected mutagenesis had revealed that the substitution of charged amino acids His 195, Arg226, Lys228, and Tyr262 in endo PG II of A. niger drastically lowers the substrate affinity by increasing the $\mathrm{K}_{\mathrm{m}}$ value more than tenfold (Armand $\boldsymbol{e t}$ al., 2000; Pages et al., 2000). Therefore, the tight substrate binding is maintained by the electrostatic interactions between the free carboxyl group of substrate and the basic amino acid residues of the active site of enzyme. The another probability is that the endo PGs enable to cleave only the non-esterified (methyl group) free polygalacturonate substrate (Shimizu et al., 2002). Subsequently, the replacement of Asp173 in the active site of enzyme slightly increases $\mathrm{K}_{\mathrm{m}}$ value (two fold), but significantly decreases the $K_{\text {cat }}$ value (Armand et al., 2000). This finding has concluded that Asp173 is responsible for catalysis and acts as a general acid catalyst that donates a proton to the glycosidic oxygen.

\section{Polymethyl galacturonase (PMG)}

Highly methylated pectin $(95 \%)$ is the best substrate for polymethyl galacturonase and its optimum $\mathrm{pH}$ lies between 4.0-5.0 (Schnitzhofer et al. 2007). Previously, Sathya et al., (1998) reported that A. niger produces highly acidic PMG (optimum $\mathrm{pH}$ 2.3). PMG acts through $\beta$-elimination mechanism and produces unsaturated oligogalacturonides from pectin polymers.

\section{Polygalacturonate lyase (PGL)}

The molecular mass of PGL varies between 30-50 kD (Sharma et al., 2012). Most of the PGL is active in alkaline pH range. The PGL from Erwinia sp. and Bacillus licheniformis showed highest activity in the range of $\mathrm{pH} 8.0-10.0$ and 6.0-11.0 respectively. The enzymatic action is very similar in all the PGL families. Generally, PGL randomly cuts pectates by $\beta$-elimination process and generates a trimeric end-product, carries an unsaturation unit at $\Delta^{4}$ position in the galacturonosyl residue at the non-reducing end (Petersen et al., 1997). The reaction occurs in three steps: (a) calcium ion and asparagine help to neutralize the carboxyl group nearby to the attacking glycosidic bond, (b) abstraction of the C5 proton is mediated by arginine, and (c) transfer of the proton to the glycosidic oxygen, resultant is formation of a double bond in between C4 and C5 at the nonreducing end of the product (Sharma et al., 2012). Pickersgill et al., (1994) and Herron et al., (2003) had revealed that $\mathrm{Ca}^{2+}$ is essential for in-vitro activity of Pel C. The $\mathrm{Ca}^{2+}$ ions create link between oligosaccharide, and protein and it also appears to the nearby uronic acid moieties within a single pectate chain. In this system, position of $\mathrm{Ca}^{2+}$ is quite different from the position of $\mathrm{Ca}^{2+}$ in PGA, where $\mathrm{Ca}^{2+}$ ions help to link PGA helices together (Walkinshaw and Arnott 1981a, b; Jayani et al., 2005)

\section{Pectin lyase (PL)}

The molecular weight of PL lies in between 30-40 kD (Soriano et al., 2005; Hayashi et al., 1997), having isoelectric point within the range of 3.5. Generally, $\mathrm{PL}$ is active in acidic $\mathrm{pH}$ range of 4.0-7.0, but there are some reports about the activity of PL in alkaline conditions (Sakiyama et al., 2001; Moharib et al. 2000). The optimum $\mathrm{pH}$ and temperature of $\mathrm{PL}$ from $A$. niger were 4.8 and $35^{\circ} \mathrm{C}$ respectively (Sathya et al., 1999). The $K_{m}$ value for PL depends on the substrate specification and it remains within the range of $0.1-5 \mathrm{mg} / \mathrm{ml}$ (Sakiyama et al., 2001; Moharib et al., 2000). The mechanism of catalysis is very similar to PGLs and this also occurs via $\beta$-elimination; however, substrate specification and cofactor requirement are not the same as PGL. The activity of PL is $\mathrm{Ca}^{2+}$ independent and highly methylated pectin is the best substrate in comparison with PGLs which act on the non-methylated substrate in presence of calcium ions. Though, the crystal structures of PGL and PL are structurally almost identical having $\beta$-helix fold; they show some essential divergences in thei activity. The loop present in the active site of PL is much longer than PGL and consists of two $\beta$-strands forming an antiparallel $\beta$-sheet. The cleft of the putative active site of PL contains four tryptophans and three tyrosines. These aromatic amino acids contribute a major role in the architecture of the active site (Sharma et al., 2012).

\section{Pectin esterase or pectin methyl esterase (PE)}

Pectin methyl esterase starts de-esterification by hydrolyzing the ester bond of methylated $\alpha$-(1-4)-linked D-galacturonosyl units and the end products are negatively charged galacturonosyl polymer and methanol. Most of the microbia PEs had shown their molecular weight in between $30-50 \mathrm{kD}$ (Hadj et al., 2002; Christensen et al., 2002) and pI varies from 4.0-8.0. Except the PE from Erwinia (alkaline PE), the optimum $\mathrm{pH}$ of others PEs varies in between 4.0-7.0. The optimum temperature of most $\mathrm{PE}$ varies in between $40-60{ }^{\circ} \mathrm{C}$ (Sharma et al. 2012). The molecular structure of $P E$ reveals that the location of active site and substrate binding cleft are very similar to PGL and PL. In this manner, the central portion of the substrate binding cleft is surrounded by several aromatic amino acids, whereas Asp136 and Asp157 are present in the centre of the active site (Sharma et al., 2012). Johansson et al., (2002) had shown the role of Asp136 and Asp157 for the action of PE. Asp157 exerts the nucleophilic attack on the carboxy methyl carbonyl carbon and Asp136 may act proton donor (acid) in the first cleavage step during releases of methanol. At the later stage, Asp136 extracts hydrogen from an incoming water molecule and cleaves the association between enzyme-substrate complexe for reactivation of the active site of the enzyme.

\section{THE MOLECULAR BASIS OF STRUCTURE FUNCTION RELATIONSHIP}

The molecular basis of enzymatic action had been elucidated after the determination of three-dimensional structures of pectinases. Keen et al., (1984) first cloned the pelC (pectate lyase C) gene of Erwinia chrysanthemi in Escherichia coli and the crystal structure of PelC of Erwinia chrysanthemi was elucidated by Yoder $\boldsymbol{e t}$ al., (1993). Later, the structural configuration of the pectinases family had subsequently revealed. These pectinases were pectate lyase A (PelA) (Thomas et al., 2002) and PelE (Lietzke et al., 1994) of Erwinia chrysanthemi, Pel of Bacillus subtilis (BsPel) (Pickersgill et al., 1994), high alkaline pectate lyase of Bacillus sp. (Akita et al., 2000), pectin lyases A (PLA) (van Alebeek et al., 2002) and pectin lyases B (PLB) (Vitali et al., 1998) from Aspergillus niger, polygalacturonase of Erwinia carotovora (Pickersgill et al., 1998), endo-polygalacturonase I and II from A. niger (Van Pouderoyen et al., 2003; Van Santen et al., 1999), polygalacturonase of Aspergillus aculeatus (Cho et al., 2001), endopolygalacturonase of Fusarium moniliforme (Federici et al. 2001); pectin methylesterases from Daucus carota (Johansson et al., 2002), PemA from E. chrysanthemi (Di Matteo et al., 2005) and rhamnogalaturonase A of Aspergillus aculeatus. (Petersen et al., 1997). Another report had suggested that the pectin lyase A of two strain of A. niger, N400 and 4M-147 has some dissimilarity in the loop conformation, made by amino acid residues $182-187$ (Mayans et al., 1997). Figure 2 shows the ribbon diagram of few pectinases from various sources.

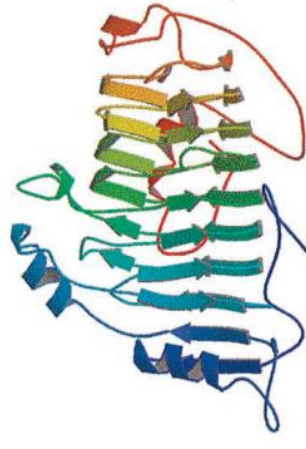

Pectate lyase $\mathrm{C}$ of $E$

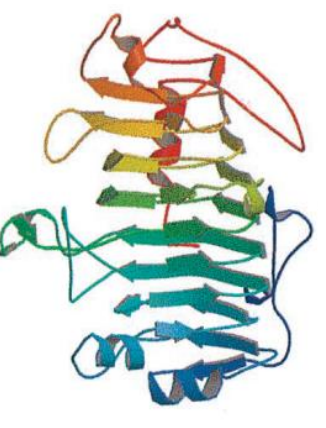

Pectate lyase E of E. chrysanthem

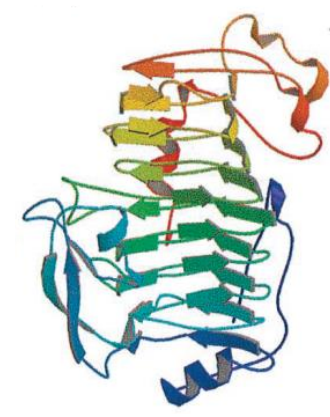

Pectin lyase B of $A$. niger.

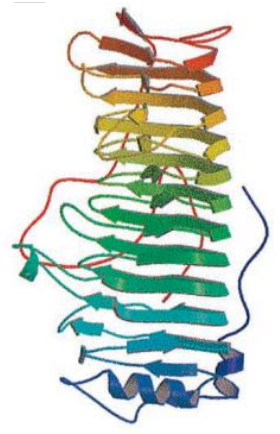

Polygalacturonase of $E$. carotovora.

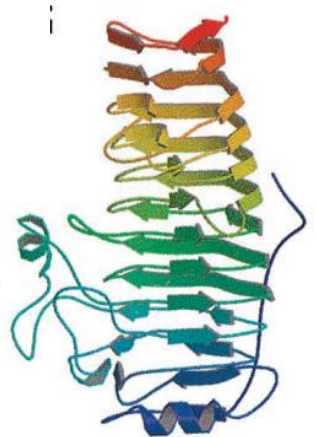

Rhamnogalacturonase A of $A$. aculeatus

Figure 2 Structural presentation of five different pectinases those are configured by parallel $\beta$ helix motif. The major portions of secondary structure of these enzymes are constructed by $\beta$ strands, and the coils represent $\alpha$ helices (Figure adopted from Herron et al., 2000) 
PNL, PL, PG, and PE are the predominant pectinases and their sequences are available in GeneBank of NCBI. The multiple sequence alignment study can give the idea about diversity and evolutionary relationship of the pectinases from different sources and also provide the information to design the global primer for PCR application and enormous expression.

In silico study had revealed that the similarity in base sequences is present in the different pectinases. The enzymes were classified in different groups on the basis of source organisms and mode of action (Yadav et al., 2009). This study also indicated that the unique similar type domains are available in pectin lyase, pectate lyase and also in pectin esterase. While polygalacturonases have another unique domain; they belong to glyco-hydrolases 28 . The multiple sequence alignment study of pectinases had shown a homology at the residues from 317 to 440 and from 553 to 676 . Yadav et al., (2009) also observed that a conserved protein sequences from residues 553 to 679 and from 680 to 806 are present in 48 protein sequences of pectin lyases. The mechanism of catalysis of the hydrolases and the lyases are completely different but in both cases, the substrate binding sites lie in a cleft which appears as the exterior part of the parallel $\beta$-helix (Herron et al., 2000). Previously, Xiao et al., (2012) reported that the gene of pectate lyase of Bacillus subtilis 521 encoded 420 amino acids with $37 \%$ negatively charged residues and $39 \%$ positively charged residues. The proteomics study of pectate lyase from Bacillus subtilis 521 had shown high homology to those from other bacteria. The catalytic domains are present in two positions 45QTDASNGANYITMS-258, 296-VQRAPRVRFGQVHVYN -312 and the catalytic activity is $\mathrm{Ca}^{+2}$ dependent. The gene sequence of pectate lyase had shown $26-82 \%$ similarity with other bacteria (B. licheniformis and $B$ amyloliquefacien)

\section{Pectate lyases}

The study of three dimensional structure of pectinolytic enzymes had indicated that there is a common structural configuration among the enzymes. The crystal structures of pectate lyase $\mathrm{C}$, pectate lyase $\mathrm{E}$ and pectate lyase of Bacillus subtilis were comprised by a right-handed parallel $\beta$-helix and a major loop region (Mayans et al., 1997). Henrissat et al., (1995) had indicated that Asp184 and Arg279 are invariant amino acid residues in the pectate and pectin lyase family. Other conserved amino acids Val-Trp-Ile-Asp-His (Val, Ile substitutable) are present at the opposite side of the parallel $\beta$ helix. The presence and importance of right-handed $\beta$ - helix in various pectinolytic enzymes like pectin lyase $B$ pectate lyase $\mathrm{C}$, pectate lyase $\mathrm{E}$ and bacterial pectate lyase had been reported by several works (Yadav et al., 2009). In addition to the $\beta$-helix structure, uncommon configuration like $(\alpha / \alpha)$ toroid and $(\alpha / \alpha)$ barrel structure had been observed in Cellvibrio japonicus and Yersinia enterocolitica separately (Gummadi et al., 2003; Natada et al., 2000).

An early study indicated that pectate lyase $\mathrm{C}$ is composed of 353 amino acids, with two disulfide bonds (Keen et al., 1984) and $\mathrm{Ca}^{2+}$ is necessary for its activity. The detailed structure of pectate lyase $\mathrm{C}$ from Erwinia chrysanthemi had revealed that there are eight coils in the right-handed parallel beta helix and each comprises three $\beta$ strands, joined by three turns. Within this topology, three parallel $\beta$ sheets are formed due to staking of the coils and the structure is stabilized by an extensive network of inter-strand hydrogen bonds. The core of the parallel $\beta$ helix contains hydrophobic, aromatic, or polar amino acids. These amino acids are oriented toward the interior, make arrangement in a row with amino acids of neighboring coils; thus, form long ladders. The amino acids of exterior part are randomly oriented and form loops of varying length which protrude from the central core (Herron et al., 2000). Another isoenzyme of pectate lyase $\mathrm{C}$ is pectate lyase $\mathrm{E}$ which shares $22 \%$ sequence identity and contains a single disulfide bond. The later is associated to a different subfamily of pectate lyases. In compare to PelC, the charged amino acids are randomly distributed on the surface of pectate lyase E. The sequence based study of 14 extracellular pectate lyases, 7 pectin lyases had revealed that there are 10 invariant amino acids which are arranged in a cluster around the active site and out of them, 5 amino acids have been associated in catalysis. The catalytically important amino acids are Asp-131, Asp-144, His-145, Thr-206, and Arg-218, while, other five amino acids (Gly-6, Gly-12, Gly-13, Trp-142, and Pro-220) are chemically inert. Moreover, there are two distinct clusters of amino acids; Asp131, Arg-218, and Pro-220 are present in the region of the $\mathrm{Ca}^{2+}$ binding site which is the part of the active site, other seven amino acids are distributed on the opposite side of the parallel $\beta$ helix (Herron et al., 2000; Henrissat et al., 1995) Site-directed mutagenesis study had indicated that alteration of amino acids around the $\mathrm{Ca}^{2+}$ binding site and Asp-131 and Arg-218 reduce the pectolytic activity (Kita et al., 1996)

\section{Pectin lyases}

Pectin lyases and pectate lyases have similar type of enzymatic activity but each enzyme recognizes a different substrate. The pectin lyase A from two strains of Aspergillus niger, N400 and 4M-147 contains 359 residues in their mature form (Mayans et al., 1997). They share common structural features with only $17 \%$ sequence identity. The protein sequences (from $\mathrm{N}$ terminus) of these two strains differ in nine amino acid substitutions: Glu12 $\rightarrow$ Lys, Asp19 $\rightarrow$ Ser, Val101 $\rightarrow$ Thr,
Gly213 $\rightarrow$ Ala, Cys248 $\rightarrow$ Ala, Phe253 $\rightarrow$ Trp, Ala289 $\rightarrow$ Glu, Thr296 $\rightarrow$ Ser and Cys317 $\rightarrow$ Ser (from strain N400 to strain 4M-147 and number started from N terminal). The pectin lyase from strains $\mathrm{N} 400$ and $4 \mathrm{M}-147$ folds into a large right-handed cylinder, made by parallel $\beta$-helix which is common structural configuration of various pectinolytic enzymes. The core of the cylinder is composed by seven to nine complete helical turns and each consists of three parallel $\beta$-strands with unique arrangement. In this topology, the strands of consecutive turns are stacked to form three parallel $\beta$-sheets called PB1 (contains eight $\beta$ strands), PB2 and PB3 (contains nine $\beta$ strands) which are stabilized by extensive network of inter-strand hydrogen bonds. PB1 and PB2 give an antiparallel $\beta$ structure, while PB3 lies approximately at right angle to PB2 (Mayans et al., 1997; Sharma et al., 2012). There are three turns T1 (between PB1 and PB2), T2 (between PB2 and PB3) and T3 (between PB3 and PB1) within the $\beta$ sheets. Among these, T1 is the $\beta$ arch type and T2 is in the $90^{\circ}$ direction to the polypeptide backbone (Fig. 3). These turns also contain asparagine ladder and the structure of T3 loop is hold up by two disulphide bridges, Cys63-Cys82 and Cys72-Cys206; while, T2 loop is preserved by a single disulphide bond (Cys302-Cys310). The N-terminal tail packs against PB2; whereas, a highly conserved amphipathic $\alpha$ helix is present in C-terminal tail which lies across PB3 and packs against the T2 turn. The maximum conserved part of PB2 and PB3 is in the asparagine ladder in T2 and the Val-Trp-Ile-AspHis pattern in PB2. All these parts contribute to structural conservation of parallel $\beta$-helix structure; while, diversity is present around the active site. These findings indicate that the conserve tails support the evolutionary relationship between pectate and pectin lyases.

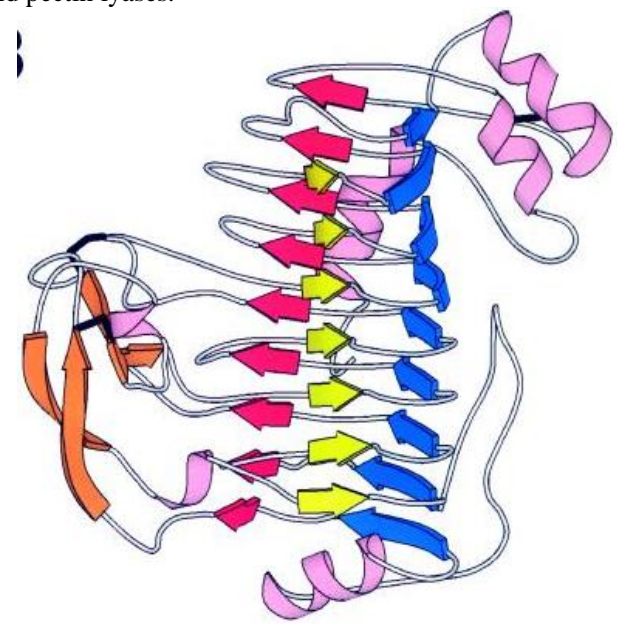

Figure 3 Secondary structure of pectin lyase B. Pink coils indicates the helices and arrows represent the $\beta$ strands. Yellow arrows are given for PB1; PB2 is blue; and PB3 is red. The orange arrows indicate the antiparallel $\beta$ structure within the first T3 turn and a short $\beta$ strand within the third T3 loop. The thick, black lines are given to indicate disulfide bonds. This image was developed by MOLSCRIPT, adopted from (Kraulis, 1991).

Although, all the pectinolytic enzymes share the same parallel $\beta$ helix topology, the mechanism of breakdown of pectin is different among the esterases, hydrolases and lyases. The substrate binding site of these enzymes has common sequence similarity and is present in the similar position within a cleft. This site is present at the exterior site of the parallel $\beta$-helix between one side of PB1 and the protruding loops (Kita et al., 1996; Sharma et al., 2012). While, the structural differences within the loops are associated to the catalytic activity and their properties. The substrate-binding site of pectate lyases are present between the long T3 loops and PB1 (Henrissat,et al., 1995). The cleft is dominated by aromatic residues, comprising four tryptophans (Trp66, Trp81, Trp151 and Trp212) and three tyrosines (Tyr85, Tyr211 and Tyr215). They form three pairs of residues (Trp81-Trp151, Trp66-Trp212 and Tyr211-Trp212) which are essential for the architecture of the binding cleft. The charged amino acids Asp154, Arg176 and Arg236 within the active site exert catalytic power (Mayans et al., 1997). Replacement of Trp62 with the aliphatic amino acids in egg white lysozyme through site directed mutagenesis studies had indicated that aromatic residues prefer binding with uncharged polysaccharides during reaction. Moreover, the substrate-binding region of pectate lyases abundantly carries charged acidic and basic amino acids for substrate recognition. In certain cases $\mathrm{Ca}^{2+}$ plays a vital role; for example, $\mathrm{Ca}^{2+}$ binds with three aspartate residues: Asp184, Asp223 and Asp227 at the bottom of the substrate-binding cleft of BsPel (Bacillus subtilis pectate lyase). Among these three amino acids, Asp184 and Asp227 are absolutely conserved, while Asp223 may be replaced by another acidic amino acid glutamate. In contrast, the pectin lyase A contains Arg176 
similar to Asp223, and Val180 is equivalent to Asp227; while, Asp154 is comparable to Asp184 of pectate lyase and Arg236 (pectin lyase numbering) in binding cleft is preserved among the extracellular pectate and pectin lyases families. Thus, it is presuming that extracellular pectate and pectin lyases had been arisen from a common ancestral lyase. Generally beta elimination reaction is very similar to acid base catalysis and some time metal ions have vital role in activation. The carboxylate anion group at $\mathrm{C} 6$ position of pectate interacts with $\mathrm{Ca}^{2+}$ ion in pectate lyase and stabilizes the substrate binding, because $\mathrm{Ca}^{2+}$ binds with Asp223 which forms the environment equivalent to Arg176 in pectin lyase. The bound $\mathrm{Ca}^{2+}$, forms an elongated ribbon of positive potential which is complementary to the negatively charged pectate substrate. Thus, the roles of $\mathrm{Ca}^{2+}$ in pectate lyase and the arginine in pectin lyase A are very similar in respect of stabilizing negatively charged substrates. The resultant is catalysis by pectate lyase is $\mathrm{Ca}^{2+}$ dependent but pectin lyase does not.

\section{Polygalacturonases}

Mukadam et al., (2010) reported that the length of gene of polygalacturonase of Aspergillus species ranges from 1107 to 2495 nucleotides. They had isolated polygalacturonase I from Aspergillus niger which contains 1101 nucleotides and 367 amino acids. The multiple sequence alignment of amino acid sequence of polygalacturonase enzyme from different fungal species like A. niger (XM 001389525; Pel et al., 2007) and A. fumigatus (XM 746347; Nierman et al., 2005) shares $96 \%$ and $76 \%$ similarity respectively.
All the polygalacturonases (endo or exo) are in glycoside hydrolase family 28 (GH28). The results of analysis of amino acid sequence of all the polygalacturonases from various sources have shown the four highly conserved regions (Palanivelu, 2006). The amino acid residues of these four motifs are NTD, G/QDD, G/SHG, RIK. Among these four regions, the two are catalytic regions (G/QDD and G/SHG) and the other two are substrate-binding regions The distances (number of amino acids) between these conserved motifs are specifically maintained in most of the cases. The average amino acids between $\mathrm{NTD} \rightarrow$ QDD, QDD $\rightarrow$ GHGMSIGS, GHGMSIGS $\rightarrow$ RIK are 21-22, 22-28, 30-40 respectively (Table 3 ). This precise distance among the highly conserved motifs may be essential for substrate binding and catalysis. Palanivelu (2006) also reported that acidic amino acid Asp and basic amino acid His are responsible for catalysis of glycosidic bond in polygalacturonates (pectates). Here, His acts as a proton donor and the Asp acts as a nucleophile and the reaction is very similar acid base catalysis (Fig. 4). This reaction mechanism is very similar to other glycosidases like levansucrases (Chambert et al., 1976), $\alpha$-amylases (Tao et al. 1987; van der Maarel et al., 2002), and xylanases (Jeffries, 1996). Furthermore, the mutation at the His188 drastically affects the enzyme activity and indicates that the highly conserved His 188 is essential in the active site. Alteration of a critical Asp212 by Glu or Asn of polygalacturonase from Fusarium moniliforme did not show any activity. Thus Asp212 acts as nucleophile instead of proton donor because replacement of Asp212 by Glu must be shown some catalytic activity

Table 3 Conserved motifs and distance between motifs of polygalacturonases from various sources. Numbers of amino acids between the conserve motifs are minutely variable. (Sequences are taken from SWISSPROT/ TrEMBL database, adopted from Palanivelu, 2006).

\begin{tabular}{|c|c|c|c|c|c|c|c|}
\hline $\begin{array}{l}\text { Name of the } \\
\text { organism }\end{array}$ & $\begin{array}{l}\text { Motif I } \\
\left({ }^{*} \text { Substrate }\right. \\
\text { binding } \\
\text { site) }\end{array}$ & $\begin{array}{l}\text { Distance } \\
\text { between } \\
\text { motif } \\
\text { (number of } \\
\text { amino acids) }\end{array}$ & $\begin{array}{l}\text { Motif II } \\
(* \text { Catalytic } \\
\text { site) }\end{array}$ & $\begin{array}{l}\text { Distance } \\
\text { between } \\
\text { motif } \\
\text { (number of } \\
\text { amino } \\
\text { acids) } \\
\end{array}$ & $\begin{array}{l}\text { Motif III } \\
\text { *Catalytic site) }\end{array}$ & $\begin{array}{l}\text { Distance } \\
\text { between } \\
\text { motif } \\
\text { (number of } \\
\text { amino } \\
\text { acids) } \\
\end{array}$ & $\begin{array}{l}\text { Motif IV } \\
(* \text { Substrat } \\
\text { e binding } \\
\text { site) }\end{array}$ \\
\hline \multicolumn{8}{|l|}{ Bacteria } \\
\hline $\begin{array}{l}\text { E. carotovora } \mathbf{P} \\
26509\end{array}$ & ${ }^{201}$ NTD & 21 & ${ }^{222}$ GDD & 28 & ${ }^{250}$ GHGMSIGS & 30 & ${ }^{280} \mathrm{RIK}$ \\
\hline $\begin{array}{l}X . \quad \text { campestris } \\
\text { Q8P582 }\end{array}$ & ${ }^{243}$ NTD & 22 & ${ }^{265} \mathrm{GDD}$ & 26 & ${ }^{291}$ THGISIGS & 40 & ${ }^{331}$ RIK \\
\hline $\begin{array}{l}P . \quad \text { syringae } \\
\text { Q87Y49 } \\
\text { Fungi }\end{array}$ & ${ }^{293}$ NTD & 22 & ${ }^{315}$ GDD & 27 & ${ }^{342}$ GHGLSIGS & 35 & ${ }^{377}$ RIK \\
\hline $\begin{array}{l}\text { S. cerevisiae } \\
\text { (endo) } \mathbf{P} 47180\end{array}$ & ${ }^{177}$ NTD & 22 & ${ }^{199}$ QDD & 22 & ${ }^{221}$ GHGISVGS & 34 & ${ }^{255}$ RIK \\
\hline $\begin{array}{l}\text { A. niger (endo } \\
\text { II) } \mathrm{P} 26214\end{array}$ & ${ }^{178}$ NTD & 22 & ${ }^{200} \mathrm{QDD}$ & 22 & ${ }^{222}$ GHGLSIGS & 34 & ${ }^{256}$ RIK \\
\hline $\begin{array}{l}\text { A. tubingensis } \\
\text { (exo) Q } 0093\end{array}$ & ${ }^{221}$ NTD & 22 & ${ }^{243}$ GDD & 23 & ${ }^{266}$ SHGISVGS & 36 & ${ }^{302}$ RIK \\
\hline $\begin{array}{l}C . \quad \text { carbonum } \\
\text { (exo) } \mathrm{Q} 00359\end{array}$ & ${ }^{227}$ NTD & 22 & ${ }^{249} \mathrm{GDD}$ & 23 & ${ }^{272}$ SHGISVGS & 36 & ${ }^{308}$ RIK \\
\hline
\end{tabular}




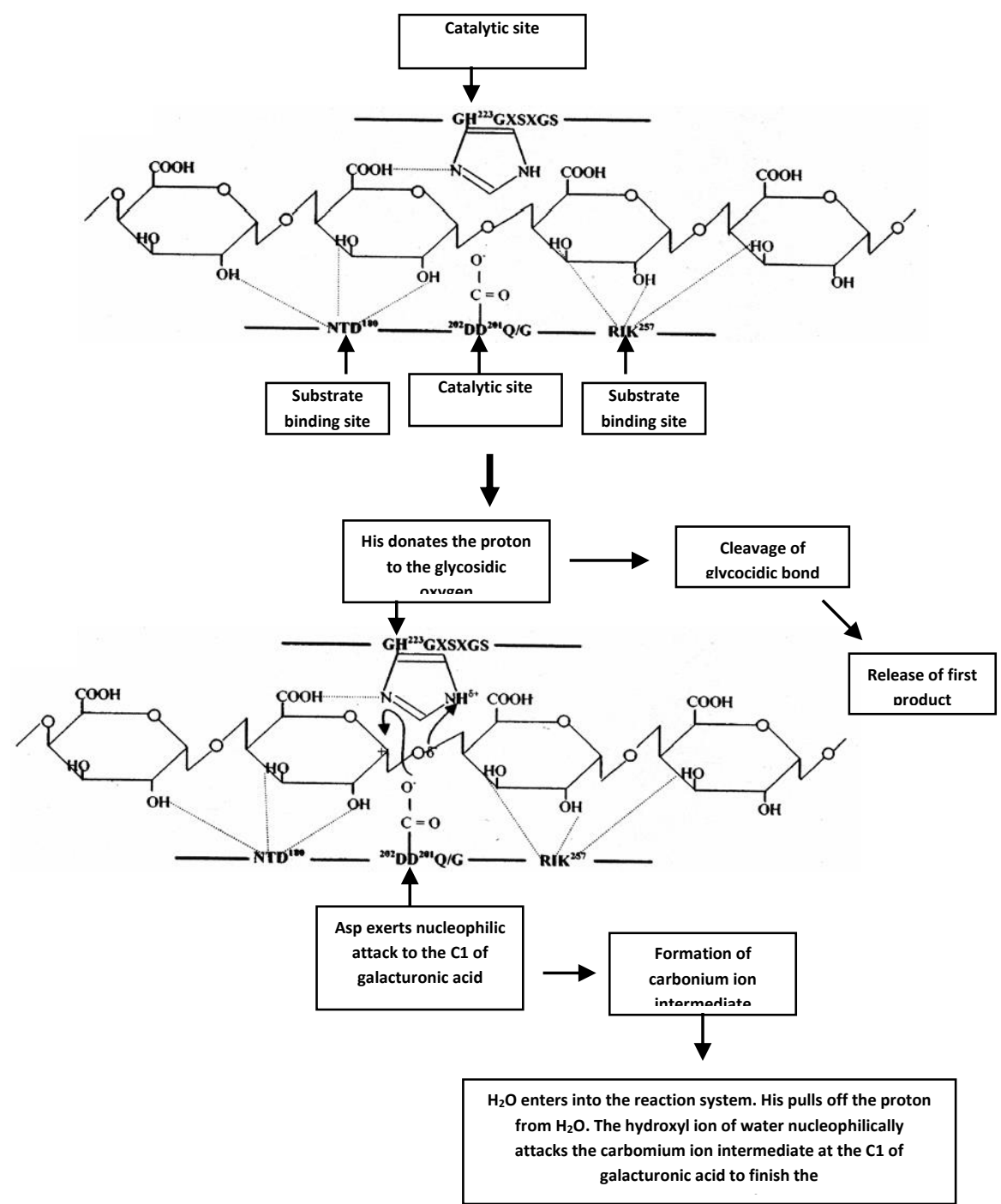

Figure 4. Mechanism of action of polygalacturonase from A. niger. The primary figure adopted from Palanivelu, 2006 and modified.

The X-ray crystallographic study had indicated that His is present in the catalytic site and can act as a proton donor. Previously, Schroter et al., (1999) stated that polygalacturonases act in acidic $\mathrm{pH}$ optima and a protonated His in the active site plays vital role. The presence of His in active site of polygalacturonase of Aspergillus ustus was also reported by Rao et al., (1996). Caprari et al., (1996) had performed the site-directed mutagenesis study on Fusarium moniliforme and suggested that His234 is the critical amino acid in the polygalacturonases which is present in highly conserved $\mathrm{GH}_{234}$ GXSIGS region. The replacement of $\mathrm{His}_{234}$ by another basic amino acid Lys totally stopped the catalytic function, as the $\mathrm{pI}$ of His and Lys are 7.59 and 9.74 respectively. Another study of site-directed mutagenesis for substitution of His223 by four different amino acids in endopolygalacturonase II from A. niger (Armand et al., 2000) completely decreases the substrate affinity as well as enzyme activity. Polygalacturonases from various organism E. caratovora (Pickergill et al., 1998), A. niger (van Santen et al., 1999) and $F$. moniliforme (Federici et al., 2001) have also exhibited similar structural motifs (right- handed parallel $\beta$-helix) like pectin and pectate lyases. Moreover, the enzymes have two loop regions which form a tunnel like substratebinding site and all the four conserved regions are present in this cleft site. The Asp of $\mathrm{G} / \mathrm{QDD}$ and His of GHGMSIGS region are located within $5.5 \AA$ distance and optimally serve as a nucleophile and a proton donor, respectively (Palanivelu, 2006).

\section{Pecti methylesterase (PME)}

Pectin methylesterase (PME; E.C.3.1.1.11) belongs to family 8 carbohydrate esterase (CE8). The multiple sequence alignment study had revealed that there were some conserved and semi-conserved amino acid residues in the PME from various sources. Like other pectinolytic enzymes, PME is also comprised by right handed parallel $\beta$-helices and above $80 \%$ amino acid residues reside in mostfavorable region of the Ramachandran plot (Rajulapati et al., 2018).

\section{APPLICATIONS OF MICROBIAL PECTINASES}

Pectinases are the most useful industrial enzymes. They have been used in several industries for processing of fruits and vegetables, beverages and wine, tea, coffee, textile material, and animal feed. Beside these, other arena of applications of these enzymes are plant fiber processing, saccharification of polysaccharide substrates, extraction of vegetable oil, degumming of plant bast fibers, bio-bleaching of kraft pulp, making of paper pulp, recycling of wastepaper, treatment of pectinacious waste in industrial effluents, and plant viruses purification (Salazar and Jayasinghe, 1999; Reid and Richard, 2004; Viikari et al., 2001; Garg et al., 2016; Pasha et al., 2013). Commercial application of pectinolytic enzymes in fruit juice processing can improve the texture, firmness, and clarification of the processed juices (Fayyaz et al., 1993).

\section{Fruit juice extraction}

Pectinases have potential applications in fruit juice preparation and clarification and have the largest demand among the enzymes those are used in food processing industry. Natural pectins increase the fruit juice viscosity and turbidity. Generally, the consumers prefer less viscous, clear and highly nutritive fruit juice for consumption. Several authors had critically pointed out that pectinases have the ability to decrease the viscosity as well as color; clarification of the fruit juice is also done by enzymatic degradation of pectin polysaccharides of fruit pulps (Junwei et al., 2000; Kareem and Adebowale, 2007; Chaudhri and Suneetha, 2012; Makky and Yusoff, 2015). A combine treatment of pectinases, cellulases, arabinases and xylanases can improve the extraction efficiency and yield volume of the fruit juices (Gailing $\boldsymbol{e t}$ al., 2000). Removal of pectin depends on the biochemical constituents of juice, type of enzyme applied and the duration of incubation (Versari et al., 1997). Physicochemical parameters for pectin degradation in juices (orange, dragon, apple, pear, grapes, guava, banana, papaya etc.) have been maintained in following conditions: $\mathrm{pH}$ 2.5-6, duration of treatment varies from 5 min to $6 \mathrm{~h}$, temperature ranges below $50^{\circ} \mathrm{C}$ and the amount of enzyme maintains in ranges from 0.06 to $0.135 \% \mathrm{v} / \mathrm{w}$ (Soares et al., 2001; Croaka and Corredig, 2006; Singh and Gupta, 2004; Tochi et al., 2009; Aliaa et al., 2010; Dang et al., 2012).

Fruit juices contain polysaccharides (pectin, cellulose, hemicellulose, lignin, and starch), protein, tannin, and metals and naturally appear as cloudy (Vaillant $\boldsymbol{e}$ al., 2001). The percentage of pectin content varies in fresh fruits (apple - 0.5-1.6, banana - 0.7-1.2, guava - 0.7-1.5, grape - 0.2-1, pineapple - 0.3-0.6, strawberries - 
0.6-0.7) which leads to colloid formation and creates problems during the processing of clear fruit juices. Sulaiman et al., (1998) reported that suspended particles in the pulp can be eliminated by filtration technique, but the presence of pectin in the solution makes this method difficult. In the food industry, the principal purpose of the clarification process is to eliminate constituents responsible for the turbidity, viscosity and cloudiness in freshly produced juice Reduction of turbidity by enzymatic depectinisation is also a potential choice for fruit juice preparation (Kashyap et al., 2001; Landbo et al., 2007). Generally, different types of pectinases (e.g., pectinase, pectinesterase, polygalacturonase, and pectin lyase) use to degrade pectic substances. Among them, polygalacturonase depolymerises the polygalacturonic acid chain, while pectin lyase depolymerises the high esterified pectin and pectin esterase hydrolyses the methoxy group of the pectin chain. The result is loss of viscosity and cluster formation, which are advantageous in separation through centrifugation or filtration processes. Finally, the juice prepared through this process, appears as higher clarity with more concentrated flavour and colour (Abdullah et al., 2007; Kaur et al., 2004). Citrus fruits juices (orange, lemon) are one of the common commercial food products and pectinolyytic enzymes are used to remove the cloudiness and stabilization of juice (Braddock, 1981). Application of pectin esterase at the natural condition of citrus fruit juice $(\mathrm{pH} 3.8)$ helps to aggregate the cloud particles from the juice within a few minutes Croaka and Corredig, (2006).

Application of pectinases in fruit juice preparation also promotes the liberation of phenolic substances from the fruit skin (Sharma et al., 2013a). This treatmen increases the phenolics content up to $15 \%$ which indicates the rich antioxidan capacity of the fruit beverages (Aliaa et al., 2010). These phenolic components play a significant role to reduce the oxidative stress and exert protective measures against cardiovascular disease and cancers (Miller and Rice-Evans, 1997).

\section{Preparation of jams and jellies}

During the preparation of jams, jellies, excess amount of sugar is added for gelation. The use of pectin esterase lowers the sugar requirements, because pectin esterase converts high methoxylated pectins into low-methoxylated pectins and ultimately increases gelation property in association with calcium (Kubra $\boldsymbol{e t}$ al., 2018).

\section{Bio-scouring of cotton fibers in textile processing}

Bio-scouring is an ideal eco-friendly technique for removal of non-cellulosic contaminants from the fiber by enzymatic treatment and lowers the toxic effects of chemical detergent like caustic soda. Pectinases along with amylases, lipases, cellulases and hemicellulases have been applied to remove sizing agents from cotton in a safe and eco-friendly manner (Wang et al., 2007) which increases the quality of the cotton without any detrimental effect (Jayani et al., 2005; KlugSantner et al., 2006). Kalantzi et al., (2010) reported that a combination of lipase and pectinase significantly reduced the treatment time for bio-scouring and produced cotton fabrics with greater quality and excellent dyeing performance.

\section{Degumming/retting of plant bast fibers}

Bast fibers are the flexible fibers (skin fiber), contain gum and it supports the cells of phloem, provides strength to the stem. Pectin degrading enzymes are responsible for the retting and removal of gumming agents during the processing of jute, linen from flax, fibers from hemp (Cannabis sativa), ramie, kenaf (Hibiscus cannabinus), and coir from coconut husks (Chesson, 1980; Bruhlman et al., 1994). Retting is a decaying process, in which pectin substances are degraded by certain bacteria (e.g., Clostridium, Bacillus) and fungi (e.g. Aspergillus, Penicillium) to release the bast fibers associated with phloem tissue beneath the bark (Sharma and Robinson, 1983). Removal of gumming agents is the essential step for the use of fiber in textile industry. This degumming process has been made by using pectinases in combination with xylanases; the process is environmentally and economically beneficial practice and lowers the harmful effects of chemical agents used in degumming treatment (Kapoor et al., 2001) Fibers are mostly composed by cellulose in associated with hemicellulose (xylan component) and pectin. Pectin degrading microorganisms also secret xylanase but lack of cellulase. Thus, the use of microbial fermentation in jute processing is the advantageous step to increase the quality of jute without damaging the cellulosic fibers (Gomes $\boldsymbol{e t}$ al., 1992). The microbial process of degumming and retting of fiber crops occur in open fermentation system at alkaline $\mathrm{pH}(\mathrm{pH} 10)$ by several microorganisms including Cladosporium, Penicillium, Aspergillus and Bacillus sp. The additionally benefit of fermentation at high $\mathrm{pH}$ value lowers the chances of contamination. Sharma et al., (2012) reported that the microbial fermentation can able to remove more than $70 \%$ ramie gun within $24 \mathrm{~h}$ and the quality of processed fibers satisfies the standard of textile industry.

\section{Wine processing}

The use of pectinases in the wine production advances the maceration, yield of juice extraction, increases the rate of filtration, and improves the flavour and colour (Blunt, 2000; Chaudhri and Suneetha, 2012). Maceration of fruits with pectinases has been done before inoculation of alcoholic fermentation. This process intensifies the quality of wine (Praveen and Suneetha, 2014). Pectolytic enzymes are used during wine making from grape mash. This preparation reduces the viscosity of juice. The additional benefit is extraction of anthocyanins due to breakdown of cell structure which acts as color enhancer of the wine (Tucker and Woods, 1991). Bosso (1993) reported that pretreatment of fermented grapes with pectolytic enzymes gives higher levels of alcohol production. Presence of polymethyl galacturonate esterase (PMGE) in the complex of pectinolytic enzymes increases methanol content as toxic component in wine (Servili et al., 1992; Revilla and González-SanJosé, 1998). Methanol is highly toxic for human. It affects central nervous system; the outcomes are decrease level of consciousness, and poor co-ordination. Moreover, vomiting, abdominal cramp, gastrointestinal disorders are the common symptoms. Methanol also gives formate after its metabolism which binds with cytochrome oxidase, starts hypoxia at cellular level and metabolic acidosis. Kidney failure is also possible as long term effects. Therefore, restriction of pectin esterase in commercial mixtures is also essential.

\section{Improvement of chromaticity and stability of red wines}

Pectin is the common constituent of plant cell wall of any fruits which lowers the yield of alcoholic fermentation. Application of pectinolytic enzymes for maceration of fruits before alcoholic fermentation by yeast improves chromatic characteristics, turbidity and stability of red wine in comparison with untreated wines (Revilla and González-SanJosé, 2003).

\section{Tea and coffee processing}

There are mainly three types of tea: black, green and oolong. Green tea is the product of no or little fermentation, oolong tea is semi-fermented and black is full fermented. According to consumption rate, $78 \%$ of world's population uses black tea, while the consumption rate of other two types tea are approximately $20 \%$ and $2 \%$ respectively. The appearance, aroma, taste and color of individual tea are different. These characteristics depend on the oxidation products such as theaflvins, therubigins and other inherent components. Generally, tea leaves contain a wide variety of non-volatile compounds: polyphenols, flavonols and flavonol glycosides, flavones, phenolic acids and depsides, amino acids, chlorophyll and other pigments, carbohydrates, organic acids, caffeine and other alkaloids, minerals, vitamins, and enzymes (Table 4) (Chaturvedula and Prakash, 2011). The quality of tea depends on the age of the tea leaves; young tender leaves are the best for production of good quality of tea as compared to old and coarse leaves. The steps of processing of black tea are: plucking $\rightarrow$ withering $\rightarrow$ cutting/rolling $\rightarrow$ fermentation $\rightarrow$ drying $\rightarrow$ sorting/cleaning and packing.

Tea leaves content $5-6 \%$ pectic substances in the middle lamella of their cell wall; pectinases degrade the pectic substances, accelerates tea processing and reduces the foaming capacity of instant tea powders due to reduction of the water soluble pectin. Application of pectinases enzymes from fungal origin along with cellulase, and xylanase increase the black tea components such as theaflavin (TF $24.77 \%$ ), thearubigen (TR $21.52 \%$ ), caffeine (CAF), high polymerized substances (HPS $21.54 \%$ ), total liquor color (TLC), total soluble solids (TSS $17.49 \%$ ) and dry matter content (DMC) (Murugesan et al., 2002; Marimuthu et al., 2000). Previously, Senthilkumar et al., (2000) reported that crude extract of microbial enzymes from A. oryzae, A. wentii, A. tamari, A. japonicus, A. awamori and Trichoderma koningii comprise cellulase, hemicellulase, pectinase, proteinase, and other enzymes; they improve the state of fermentation and also enhance the concentration of TF by $45 \%$, TR by $48 \%$, HPS by $33 \%$, TLC by 19 $\%$ and TSS by $3 \%$ respectively. Although, enzyme treatment accelerates tea fermentation at working $\mathrm{pH}$ range of 2.5 to 6.0 , with optimum $\mathrm{pH}$ being between 3.0 to 4.0 and working temperature range of 15 to $50^{\circ} \mathrm{C}$. The concentration of the enzymes have to be controlled carefully to avoid the damage of the tea leaves (Sharma et al., 2012), because excess fermentation lowers the glaze-ness and quality of the tea leaves, decreases the color, flavor, and aroma and increases the rate of spoilage of the tea leaves.

Coffee beans are surrounded by mucilaginous (17 \% by mass) viscous coat which comprises $84 \%$ moisture with $8.9 \%$ protein, $4 \%$ sugars, $2.8 \%$ pectin and $0.9 \%$ ash (Murthy and Naidu, 2011). Soares et al., (1999) stated that application of pectinases degrade the outer mucilage cover of the coffee beans and improves the quality of coffee. A previous study had observed that pectinases from Aspergillus niger CFR degrades 54-71\% mucilaginous layer within 1 to $2 \mathrm{~h}$ of fermentation and the total process had been completed within $3.5 \mathrm{~h}$ (Murthy and Naidu, 2011). Inoculated waste mucilage of coffee pulp is used as a source of microbial pectinases and recycling process is done by spraying the filtered fermentative liquid over the coffee beans which economized the process (Soresen et al., 2000; Murthy and Naidu, 2011). 
Table 4 Different components of tea leaves and their beneficial effects.

\begin{tabular}{|c|c|c|c|}
\hline Class of components & Name of each component & \% of dry weight & Contribution \\
\hline \multirow{11}{*}{ Polyphenols/Flavanols } & \multirow{2}{*}{$\begin{array}{l}\text { Total polyphenols } \\
\text { (-) Epigallocatechin gallate }\end{array}$} & $25-35$ & Taste-astringent \\
\hline & & $9-14$ & \multirow{6}{*}{$\begin{array}{l}\text { Give golden-amber color and taste } \\
\text { Inhibit histamine release, antiallergic; } \\
\text { Act as antimutagenic and carcinogenic; } \\
\text { Protects thiol groups of protein. } \\
\text { Catechin-potent anti oxidant (25-100 } \\
\text { times more than the activity of vitamins } \\
\text { C and E). }\end{array}$} \\
\hline & (-) Epicatechin gallate & $2-4$ & \\
\hline & (-) Epigallo catechin & $3-6$ & \\
\hline & (-) Epicatechin & $1-3$ & \\
\hline & (+) Catechin & $1-2$ & \\
\hline & \multirow{2}{*}{$\begin{array}{l}\text { (+) Gallocatechin } \\
\text { Flavonols and flavonol } \\
\text { glycosides }\end{array}$} & $1-2$ & \\
\hline & & $3-4$ & \multirow{2}{*}{$\begin{array}{l}\text { Light yellow } \\
\text { Acts as anti oxidant } \\
\text { Act as anti oxidant }\end{array}$} \\
\hline & $\begin{array}{l}\text { Polyphenolic acids and } \\
\text { depsides }\end{array}$ & $3-4$ & \\
\hline & Theaflavins & $1-2$ & \multirow{2}{*}{$\begin{array}{l}\text { Taste-astringent } \\
\text { Color-yellowish brown } \\
\text { Taste- ashy and slight astringent Color- } \\
\text { reddish brown. }\end{array}$} \\
\hline & Thearubigins & $15-18$ & \\
\hline \multirow[t]{5}{*}{ Pigments } & \multicolumn{2}{|l|}{ Pheophorbide } & \multirow{5}{*}{$\begin{array}{l}\text { Color- brownish } \\
\text { Color- blackish } \\
\text { Color- creamy } \\
\text { Color- yellow } \\
\text { Color and appearance }\end{array}$} \\
\hline & Pheophytin & & \\
\hline & Leuco anthocyanins & $2-3$ & \\
\hline & Carotene & & \\
\hline & $\begin{array}{l}\text { Chlorophylls and other } \\
\text { pigments }\end{array}$ & $0.5-0.6$ & \\
\hline \multirow[t]{3}{*}{ Alkaloid } & Caffeine & $3-5$ & Taste- bitter \\
\hline & Theobromine & 0.2 & \multirow{2}{*}{$\begin{array}{l}\text { Stimulates cardiac activity, dilates } \\
\text { vessels of heart, brain and bronchi, has } \\
\text { antispasmodic and diuretic effects. } \\
\text { Potent diuretic agent and also acts as } \\
\text { vasodilator agent in heart, brain and } \\
\text { bronchi, stimulates CNS. }\end{array}$} \\
\hline & Theophylline & 0.5 & \\
\hline \multirow[t]{3}{*}{ Acids } & & & \multirow{3}{*}{$\begin{array}{l}\text { Taste- brothy } \\
\text { Produces volatile carbonyl compounds } \\
\text { during processing. } \\
\text { Stimulate release of gastric juice, } \\
\text { regulate the state of intestinal flora, } \\
\text { support normal acid-base balance, } \\
\text { activate peristaltic movements and } \\
\text { decrease risk gastro-intestinal diseases. }\end{array}$} \\
\hline & Amino acids & $2-4$ & \\
\hline & $\begin{array}{l}\text { Organic acids } \\
\text { Citric, tartaric, malic, oxalic, } \\
\text { fumaric and succinic acids, } \\
\text { palmitinic acid) }\end{array}$ & $0.5-2.0$ & \\
\hline \multirow[t]{5}{*}{ carbohydrates } & Monosaccharides & $4-5$ & \\
\hline & Polysaccharides & $14-22$ & \\
\hline & Cellulose and Hemicellulose & $6-8$ & \multirow{3}{*}{ Cell wall component } \\
\hline & Pectins & $5-6$ & \\
\hline & Lignin & $5-6$ & \\
\hline \multirow[t]{3}{*}{ General components } & Protein & $14-17$ & \multirow{3}{*}{$\begin{array}{l}\text { Have significant role in formation of } \\
\text { aroma. }\end{array}$} \\
\hline & Lipids & $3-5$ & \\
\hline & Ash (minerals) & $5-6$ & \\
\hline Aroma generating compound & $\begin{array}{l}\begin{array}{l}\text { Volatiles (more than } 600 \\
\text { types) }\end{array} \\
\end{array}$ & $0.01-0.02$ & Aroma \\
\hline \multirow[t]{4}{*}{ Flavouring agents } & \multicolumn{2}{|l|}{ Linalool, linalool oxide } & Flavour- sweet \\
\hline & \multicolumn{2}{|l|}{ Geraniol, phenylacetaldehyde } & Flavour- floral \\
\hline & \multirow{2}{*}{\multicolumn{2}{|c|}{$\begin{array}{l}\text { Nerolidol, benzaldehyde, } \\
\text { methyl salicylate, phenyl } \\
\text { ethanol } \\
\text { Trans-2-hexenal, n-hexanal, } \\
\text { cis-3-Hexenol, grassy, } \beta \text { - } \\
\text { ionone }\end{array}$}} & Flavour- fruity \\
\hline & & & Flavour- fresh flavour \\
\hline
\end{tabular}

\section{Waste water treatment}

Pectinaceous materials are commonly present in the wastewater of citrus fruits processing industry. Initially physical and chemical treatments (physical dewatering, chemical coagulation, chemical hydrolysis and methnogenesis) were the general practice for waste treatment to remove the pectinaceous materials. This process is not cost effective, time saving and eco-friendly, and creates chemical hazards. Pretreatment by pectinolytic microbes (alkalophilic Bacillus sp. GIR 621) during the activated-sludge treatment decomposes the pectinaceous materials from waste water (Tanabe et al., 1986; Tanabe et al., 1987). Food industry discharge waste effluents during processing of vegetables which carries pectin as by-product. Pectinases are used for the pretreatment of the wastewaters to remove pectin from it (Jayani et al., 2005). The application of pectinolytic organisms during activated-sludge treatment is an eco-friendly, cost effective, timesaving process.

\section{Paper and pulp industry}

In the modern biotechnological era, paper and pulp industries have started to exploit enzymes like xylanases, ligninases, mannanase and pectinases for biobleaching (Kirk and Jefferies, 1996; Bajpai, 1999; Kubra et al., 2018). Formation of sheet is a vital step in papermaking and the presence of pectins in the pulp weakens dewatering due to their high cationic demand, causes yellowness of paper (Garg et al., 2016). This problem can be solved by using pectinase (biobleaching agent) which starts depolymerization of pectin, and consequently lowers the cationic demand of pectin as compared to peroxide bleaching (Reid and Ricard, 2000; Viikari et al., 2001). The application of pectin degrading enzymes in paper manufacturing reduces the use of cationic polymers. Alkaline pectinase from streptomyces $s p$. was employed in biobleaching of pulp. Alkaline pectinases used in Japanese paper manufacturing system. This treatment improves the strength of the pulp as compared to the 
conventional soda-ash cooking method (Kubra et al., 2018). The bio-bleaching treatment of hardwood and bamboo kraft pulps is mediated by microbial pectinases and other polysaccharidases. This eco-friendly process maintains the quality and brightness of the paper as similar as conventional method but lowers the release of eco-toxic agents like organochlorine compounds in the waste water (Ahlawat et al., 2007, 2008; Dhiman et al., 2009; Kaur et al., 2010).

\section{Animal feed Processing}

Pectinolytic enzymes are applied for production of animal feeds, as the enzymes hydrolyze non-degradable bio-fibers and change the palatability of feed. The application of pectinases in animal feed production improves the quality of feed by lowering the viscosity and increases the absorptivity of nutrients. Moreover, the enzymatic treatment reduces the fiber content of the feed and enhances the liberation of nutrients trapped under the non-degradable fibers. Low fiber containing diet also reduces the amount of feces which is ecologically beneficial (Jayani et al., 2005; Praveen and Suneetha, 2014). The use of multiple enzymes like xylanases, pectinases and cellulases during preparation of ruminants' diet economically improve the quality of feeds. This supplementation increases the digestibility of organic matter by changing the fiber digestion in rumen and increases the dietary energy uptake capacity (Selinger et al., 1996; Petersen, 2001; Arambel et al., 1987; Ghorai et al., 2009). All these factors ultimately help to improve the animal weight.

\section{Purification of plant viruses}

A pure preparation of plant viruses is essential to study the physico-chemical and biological characteristics of them. In certain condition virus particles are associated to phloem tissue; application of alkaline pectinases and cellulose degrade the fibers and remove the virus form the tissue in a pure form (Jayani $\boldsymbol{e t}$ al., 2005).

\section{Vegetable oil extraction}

Traditionally, organic solvent (hexane) was used for extraction of edible oil from oil producing crops like rape seed, coconut germ, sunflower seed, palm and olives. Organic solvent like hexane is a potential carcinogen and increase the risk cancer (Kashyap et al., 2001). Bio-extraction of vegetable oils in aqueous phase can be possible by using alkaline pectolytic enzymes which rupture the plant cell wall after degradation of pectin in middle lamellae and promote the extraction of oils from the inner part of the seeds or germ layer. Application of a mixture of cellulases, hemicellulases and pectinases in oil extraction process increases the maximum yield of oil uptake. This process also improves the polyphenolic and vitamin $\mathrm{E}$ content within the oil and enriches the quantity of antioxidants (Kashyap et al., 2001; Hoondal et al., 2002; Iconomou et al., 2010)

\section{Saccharification of agricultural substrates}

Saccharification of agro-industrial wastes in presence of pectinases increases fermentable sugar content in the mixture which is used for bioethanol production (Biz et al., 2014). Different polysaccridases (pectinase, hemicellulases and cellulases) are being used for saccharification of plant cell wall polysaccharides including pectic substances into simple sugars which are used in bioethanol production (Beldman et al., 1984; Hossain et al., 2011; Collares et al., 2012).

\section{Recycling of wastepaper}

Chemically deinking process creates environmental hazards; but, enzymatic deinking reduces pollution hazards, energy consumption, disposal problems and improves the performance. A cluster of enzymes (pectinases, hemicellulases, cellulases and lignolytic enzymes) are applied during deinking process. Basically, enzymes modify the bonding characteristics between ink and fiber; the result is removal of ink from the surface of the fibers during washing (Xu et al., 2009; Pathak et al., 2010; Xu et al., 2011).

\section{A COMPARATIVE OVERVIEW ON}

THE

MAJOR

Table 5 Comperative features among the pectinases, amylases, cellulose and xylanases.

\begin{tabular}{|c|c|c|c|c|}
\hline $\begin{array}{ll}\text { Features } & \text { Enzyme } \\
\end{array}$ & Pectinases & Amylases & Cellulase & Xylanases \\
\hline Types & $\begin{array}{l}\text { Hydrolases: Pectin esterase, } \\
\text { Exo and } \\
\text { polygalacturonase, Exo and } \\
\text { Endo } \\
\text { polymethylgalacturonases, } \\
\text { Rhamnogalacturonases, } \\
\text { Xylogalacturonase. } \\
\text { Lyases: Exo and Endo } \\
\text { polygalacturonate lyase, Exo } \\
\text { and Endo }\end{array}$ & $\begin{array}{l}\text { Hydrolases: } \alpha \text { - amylase, } \\
\alpha \text {-glucosidase, } \\
\text { Isoamylase, Pullulanase, } \\
\beta \text {-Amylase, } \gamma \text {-Amylase } \\
\text { Transferases: Branching } \\
\text { enzyme, Cyclodextrin } \\
\text { glycosyl transferase. }\end{array}$ & $\begin{array}{l}\text { Endo- }(1,4)-\beta \text {-D-glucanase } \\
\text { (Endoglucanase), } \\
\text { Exo- }(1,4)-\beta \text {-D-glucanase } \\
\text { or } \quad 1,4-\beta \text {-D-glucan- } \\
\text { cellobiohydrolase } \\
\text { (Exoglucanase), } \\
\beta \text {-Glucosidase. }\end{array}$ & $\begin{array}{l}\text { Endo-1,4- } \beta \text {-xylanase, } \\
\beta \text {-D-xylosidase (xylan- } \\
1,4-\beta \text {-xylosidase), } \\
\text { Acetylxylan esterase, } \alpha \text { - } \\
\text { glucuronidase, } \\
\text { arabinofuranosidase. }\end{array}$ \\
\hline
\end{tabular}

polymethylgalacturonate lyase,

$\beta$-Glucosidase.

Rhamnogalacturonan lyases.

\section{Structure}

Single domain consists of righthanded parallel $\beta$-helix composed by parallel $\beta$-strands, the central cylinder contains seven to nine complete helical turns

Active site -

Lyase: Asp, Arg

Polygalacturonase: Asp, His $\alpha$-amylase family: primarily has three domains (A, B, C) Adomain, consists of $(\alpha / \beta)_{8}$ or TIM barrel structure. Extra domain may also be present.

$\beta$-amylase has single domain with $(\alpha / \beta)_{8}$ barrel core

Active site -

$\alpha$-amylase and others:

Asp, Glu and Asp

$\beta$-Amylase: Cys, Ser.
Most cellulases consists of multiple domains which are joined by linker sequences, contain Ser,

Thr and Pro.

Cellulases also possess $(\alpha / \beta)_{8}$ or TIM barrel structure. The catalytic centre is located at the $\mathrm{C}$ terminal ends of the bet strands; aromatic residues forming the substrate binding site.

Bacterial cellulase system

is more complex, forms, cellulosomes.

\begin{tabular}{|c|c|c|c|c|}
\hline $\begin{array}{l}\text { Mechanism } \\
\text { catalysis }\end{array}$ & $\begin{array}{l}\text { Hydrolases - } \\
\text { Endo-type: Random cleavage } \\
\text { Exo-type: Terminal cleavage } \\
\text { Lyases: } \\
\text { Endo-type: Transelimination, } \\
\text { random cleavage } \\
\text { Exo-type: Transelimination, } \\
\text { terminal cleavage. }\end{array}$ & $\begin{array}{l}\text { Hydrolases - } \\
\text { Endo-acting: } \alpha \text { - amylase - } \\
\alpha \text {-retaining double } \\
\text { displacement mechanism; } \\
\text { acid base catalysis; Glu } \\
\text { acts as proton donor and } \\
\text { one Asp acts as } \\
\text { nucleophile. }\end{array}$ & $\begin{array}{l}\text { Acid base catalysis; two } \\
\text { glutamates act as the } \\
\text { catalytic residues (one } \\
\text { Glu at } \beta \text {-strand IV is } \\
\text { proton donor, another Glu } \\
\text { at } \beta \text {-strand VII is } \\
\text { nucleophile. }\end{array}$ & $\begin{array}{l}\text { Acid base catalysis } \\
\text { (double displacement } \\
\text { mechanism); } \\
\text { Two glutamates act as } \\
\text { proton donor and } \\
\text { nucleophile at the } \\
\text { catalytic site. }\end{array}$ \\
\hline End products & $\begin{array}{l}\text { Esterases: Pectic acid }+ \\
\text { methanol / ethanol. } \\
\text { Endo-type hydrolases: Oligo- } \\
\text { galacturonates or its methyl } \\
\text { derivative. }\end{array}$ & $\begin{array}{l}\text { Endo-acting: Several } \\
\text { maltooligomers, branched } \\
\text { dextrins, maltose. } \\
\text { Exo-acting: maltose, and } \\
\text { glucose. }\end{array}$ & $\begin{array}{l}\text { Endoglucanase- } \\
\text { Reducing or non-reducing } \\
\text { cellooligosaccharides; } \\
\text { Exoglucanase- Cellobiose } \\
\beta \text {-Glucosidase- }\end{array}$ & $\begin{array}{l}\text { Xylanase produces } \\
\text { xylooligosaccharides. } \\
\beta \text {-xylosidase releases } \\
\text { xylose residues from the } \\
\text { nonreducing ends of }\end{array}$ \\
\hline
\end{tabular}




\begin{tabular}{|c|c|c|c|c|}
\hline & $\begin{array}{l}\text { Exo-type hydrolases: Mono / } \\
\text { di-galacturonate or its methyl } \\
\text { derivative. } \\
\text {.Endo-type lyases: Unsaturated } \\
\text { oligo-galacturonates. } \\
\text { Exo-type lyases: Unsaturated } \\
\text { Mono/ di-galacturonates. }\end{array}$ & & Cellobiose to glucose & $\begin{array}{l}\text { xylooligosaccharides. } \\
\text { Acetylxylan esterase } \\
\text { removes acetyl group. }\end{array}$ \\
\hline Assay methods & $\begin{array}{l}\text { Esterase: Estimation of } \\
\text { methanol; } \\
\text { Hydrolases and lyases: } \\
\text { Colorimetric assay for } \\
\text { estimation of reducing sugar by } \\
3,5 \text { dinitrosalicylic acid } \\
\text { reagent; } \\
\begin{array}{l}\text { Chromatographic study for } \\
\text { methyl derivatives } \\
\text { galacturonate. }\end{array}\end{array}$ & $\begin{array}{l}\text { Estimation of reducing } \\
\text { sugar by } \\
\text { dinitrosalicylic } \\
\text { reagent. } \\
\text { Determination of blue } \\
\text { loss property of starch } \\
\text { iodine color complex. }\end{array}$ & $\begin{array}{lr}\text { Estimation of reducing } \\
\text { sugar by r } \\
\text { dinitrosalicylic } \\
\text { reagent. } \\
\beta \text {-glucosidase activity- } \\
\text { Spectrophotometric } \\
\text { determination of p- } \\
\text { nitrophenol from the } \\
\text { substrate p-nitrophenyl- } \\
\beta \text {-D-glucoside. }\end{array}$ & $\begin{array}{l}\text { Estimation of reducing } \\
\text { sugar by } r, 5 \\
\text { dinitrosalicylic acid } \\
\text { reagent or by using copper } \\
\text { sulfate and areno- } \\
\text { molybdic acid reagent. }\end{array}$ \\
\hline Applications & $\begin{array}{l}\text { Fruit juice preparation, } \\
\text { degumming, tea and coffee } \\
\text { processing, bio-bleaching in } \\
\text { paper industry, vegetable oil } \\
\text { extraction, animal feed } \\
\text { processing, recycling of waste } \\
\text { paper, waste water treatment. }\end{array}$ & $\begin{array}{l}\text { Liquefaction of starch for } \\
\text { production of glucose } \\
\text { syrup, maltose, high } \\
\text { fructose containing syrup, } \\
\text { maltooligosaccharides } \\
\text { and others. } \\
\text { Used in backing and } \\
\text { brewing industry. } \\
\text { Textile industry for } \\
\text { desizing. } \\
\text { Clinical use- medicine as } \\
\text { digestive aids. } \\
\text { Production of ethanol. } \\
\text { Used in detergents and } \\
\text { waste water treatment. }\end{array}$ & $\begin{array}{l}\text { Pulp and paper industry, } \\
\text { textile industry, } \\
\text { bioethanol production, } \\
\text { wine and brewing } \\
\text { industry, clarification of } \\
\text { fruit juices, olive oil } \\
\text { extraction, carotenoid } \\
\text { extraction, animal feed } \\
\text { production, detergents } \\
\text { industry, } \\
\text { management. }\end{array}$ & $\begin{array}{l}\text { Pulp or paper industry, } \\
\text { food industry, extraction } \\
\text { of coffee and plant oils, } \\
\text { clarification of fruit juices } \\
\text { and wine, animal feed } \\
\text { processing, textile } \\
\text { industry, } \\
\text { production. biofuel }\end{array}$ \\
\hline
\end{tabular}

Acknowledgement: The author expresses his thanks to Dr. Amal Kanti Chakraborty, Ex-Associate Professor of English, Midnapore College Midnapore for his help in linguistic correction.

\section{REFERENCES}

ABDULLAH, A. G. L., SULAIMAN, N. M., AROUA, M. K., MEGAT, M. N. M. J. (2007). Response surface optimization of conditions for clarification of carambola fruit juice using a commercial enzyme. J Food Eng, 81, 65-71. https://doi.org/10.1016/j.jfoodeng.2006.10.013

AHLAWAT, S., DHIMAN, S. S., BATTAN, B., MANDHAN, R. P., SHARMA, J. (2009). Pectinase production by Bacillus subtilis and its potential application in biopreparation of cotton and micropoly fabric. Process Biochem, 44, 521-526. https://doi.org/10.1016/j.procbio.2009.01.003

AKITA, M., SUZUKI, A., KOBAYASHI, T., ITO, S., YAMANE, T. (2000). Crystallization and preliminary X-ray analysis of highalkaline pectate lyase. Acto Crystallogr D, 56, 749-750. https://doi.org/10.1107/S09074444900003334

ALANA, A., ALKORTA, I., DOMÍNGUEZ, J. B., LLAMA, M. J., SERRA, J. L. (1990). Pectin lyase activity in a Penicillium italicum strain. Appl Environ Microbiol, 56, 3755-3759.

ALBERSHEIM, P., DARVILL, A. G., O'NEILL, M. A., SCHOLS, H. A., VORAGEN, A. G. J. (1996). In: Visser J, Voragen AGJ (Eds) Pectins and pectinases: Elsevier Science B.V., Amsterdam, pp 47-56

ALIAA, A. R. N., MAZLINA, M. K. S., TAIP, F. S. (2010). Impact of commercial pectolytic enzymes on selected properties of white dragon fruit juice. J Inst Eng Malays, 71, 25-31.

ALIMARDANI-THEUIL, P., GAINVORS-CLAISSE, A., DUCHIRON, F. (2011). Yeasts: An attractive source of pectinases- From gene expression to potential application: A review. Process Biochem, 46(8), 15251537. https://doi.org/10.1016/j.procbio.2011.05.010

ALKORTA, J., GORBISU, G., LLAMA, M. J. AND SERRA, J. L. (1998) Industrial applications of pectic enzymes: a review. Process Biochem, 33(1), 2128. https://doi.org/10.1016/S0032-9592(97)00046-0

ALONSO, J., CANET, W., HAWELL, N., ALIQUE, R. (2003). Purification and characterization of carrot (Daucas carota L.) pectinesterase. J Sci Food Agric, 83, 1600-1606. https://doi.org/10.1002/jsfa.1591

ARAMBEL, M. J., WEIDMEIER, R. D., WALTERS, J. L. (1987). Influence of donor animal adaptation to added yeast culture and/or Aspergillus oryzae fermentation extract on in vitro rumen fermentation. Nutr Rep Int, 35, 433-437.

ARMAND, S., WAGEMAKER, M. J. M., TORRES, P. S., KESTER, H. C. M., VAN SANTEN, Y. et al. (2000). The active topology of Aspergillus niger endopolygalacturonase II as site-directed mutagenesis, J Biol Chem, 275, 691696. Available on line at http://www.jbc.org

BAJPAI, P. (1999). Application of enzymes in the pulp and paper industry. Biotechnol Prog, 15, 147-157. https://doi.org/10.1021/bp990013k
BELDMAN, G., ROMBOUTS, F. M., VORAGEN, A. G. J., PILNIK, W. (1984). Application of cellulase and pectinase from fungal origin for the liquifaction and saccharification of biomass. Enz Microbiol Technol, 6, 503-507. https://doi.org/10.1016/0141-0229(84)90004-8

BENEN, J., PARENICOVA, L., KUSTERS-VAN SOMEREN, M., KESTER, H., VISSER, J. (1996). Molecular genetic and biochemical aspects of pectin degradation in Aspergillus. In: Pectins and Pectinases, Visser, J. and Voragen, A.G.J., (Eds.), Vol. 14, Elsevier Science, Amsterdam, The Netherlands, pp. 331346

BHARDWAJ, V., DEGRASSI, G., BHARDWAJ, R. K. (2017). Microbial Pectinases and their applications in industries: A review. Int Res J Eng Technol, 4(8), 829-836. Available on line at www.irjet.net

BIZ, A., FARIAS, F. C., MOTTER, F. A., DE PAULA, D. H., RICHARD, P., KRIEGER, N., MITCHELL, D. A. (2014). Pectinase activity determination: an early deceleration in the release of reducing sugars throws a spanner in the works. Plos One, 9(10), e109529. https://doi.org/10.1371/journal.pone.0109529

BLUNT, M. K. (2000). Cellulases and related enzymes in biotechnology. Biotechnol Adv, 18, 355-383. https://doi.org/10.1016/S07349750(00)00041-0

BOSSO, A. (1993). On-skin maceration during white wine making in the presence of pectolytic enzyme preparations. Vini d'Italia, 34, 25-40.

BRADDOCK, R. J. (1981). Pectinase treatment of raw orange juice and subsequent quality changes in $60^{\circ}$ brix concentrate. Proc. Fla. State Hort. Soc 94, 270-273. https://fshs.org/proceedings-o/1981-vol-94/270273\%20(BRADDOCK).pdf

BRINTON, C. S., DORE,W. H., WICHMANN,H. J., WILLAMAN ,J. J., WILSON, C. P. (1927). Definitions written by the committee on nomenclature of pectin of the agriculture-food division. J Am Chem Soc, 49, 38-40.

BRUHLMANN, F., KIM, K. S., ZIMMERMAN, W., FIECHTER, A. (1994). Pectinolytic enzymes from actinomycetes for the degumming of ramie bast fibers. Appl Environ Microbiol, 60, 2107-2112.

BUDIATMEN, S., LONSANE, B. K. (1987). Cassava fibrous waste residue: a substitute to wheat bran in solid state fermentation. Biotechnol Lett, 9, 597-600. https://doi.org/10.1007/BF01026669

CAFFALL, K. H., MOHNEN, D. (2009). The structure, function, and biosynthesis of plant cell wall pectic polysaccharides. Carbohydrate Research 344, 1879-1900. https://doi.org/10.1016/j.carres.2009.05.021

CAPRARI, C., BERGMANN, C., MIGHELI, Q., et al. (1993). Fusarium moniliforme secretes four endopolygalacturonases derived from a single gene product. Physiol Mol Plant Pathol, 43, 453-462. https://doi.org/10.1006/pmpp.1993.1073

CAPRARI, C., MATTEI, B., BASILE, M. L., SALVI, G., CRESCENZI, V., et al. (1996). Mutagenesis of endopolygalacturonase from Fusarium moniliforme: Histidine residue 234 is critical for enzymatic and macerating activities and not 
for binding to polygalacturonase-inhibiting protein (PGIP). Mol Plant Microbe Interact, 9, 617-624.

CARROLL, S. B, GRENIER, J. K, WEATHERBEE, S. D. (2005). From DNA to diversity: Molecular genetics and the evolution of animal design. 2nd Ed. Malden: Blackwell Scientific, pp. 258.

CASTILHO, L. R., MEDRONHO, R. A., ALVES, T. L. M. (2000). Production and extraction of pectinases obtained bu solid state fermentation of agroindustrial residues with Aspergillus niger. Bioresour Technol, 71, 45-50. https://doi.org/10.1016/S0960-8524(99)00058-9

CHAMBERT, R., TREBOUL, G. G. (1976). Levansucrase of Bacillus subtilis: Characterization of a stabilized fructosyl-enzyme complex and identification of an aspartyl residue as the binding site of the fructosyl groups. Eur J Biochem, 71, 493-508.

CHATTERJEE, A. K., BUCHANAN, G. E., BEHRENS, M. K., STARR, M. P. (1979). Synthesis and excretion of polygalacturonic acid trans - eliminase in Erwinia, Yersinia and Klebsiella species. Can J Microbiol, 25, 94-102. https://doi.org/10.1139/m79-014

CHATURVEDULA, V. S. P., PRAKASH, I. (2011). The aroma, taste, color and bioactive constituents of tea. J Med Plants Res, 5(11), 2110-2124. Available online at http://www.academicjournals.org/JMPR

CHAUDHRI, A., SUNEETHA, V. (2012). Microbially derived pectinases: a review. IOSR J Pharm Biol Sci, 2, 01-05. www.iosrjournals.org.pdf

CHESSON, A. (1980). Maceration in relation to the post-harvest handling and processing of plant material. $J$ Appl Bacteriol, 48, 1-45. https://doi.org/10.1111/j.1365-2672.1980.tb05204.x

CHO, S. W, LEE, S., SHIN, W. (2001). The X-ray structure of Aspergillus aculeatus polygalacturonase and a modeled structure of the polygalacturonaseoctagalacturonate complex. $J$ Mol Biol, 311, 863-878. https://doi.org/10.1006/jmbi.2001.4919

CHRISTENSEN, T. M., NIELSEN, J. E., KREIBERG, J.D., RASMUSSEN, P MIKKELSEN, J. D. (1998). Pectin methyl esterase from orange fruit: characterization and localization by in situ hybridization and immunohistochemistry. Planta, 206, 493-503. https://doi.org/10.1007/s004250050426

COLLARES, R. M., MIKLASEVICIUS, L. V. S., BASSACO, M. M., SALAU, N. G. P., MAZUTTI, M. A., BISOGNIN, D. A., TERRA, L. M. (2012) Optimization of enzymatic hydrolysis of cassava to obtain fermentable sugars. $J$ Zhejiang Univ Sci B (Biomed \& Biotechnol), 13(7), 579-586. https://doi.org/10.1631/jzus.B1100297

COOPER, R. M. (1983). The mechanisms and significance of enzymic degradation on host cell walls. In: Callow JA, Ed. Biochemical Plant Pathology. Wiley, Chichester, New York, pp. 101-37.

CORNICK, N., JENSEN, N., STAHL, D., HARTMAN P., ALLISON, M (1994). Lachnospira pectinoschiza sp. nov., an anaerobic pectinophile from the pig intestine. Int $J$ Syst Bacteriol, 44(1), 87-93. https://doi.org/10.1099/00207713-44-1-87

CORREDIG, M., KERR, W., WICKER, L. (2000). Separation of thermostable pectinmethylesterase from marsh grapefruit pulp. J Agric Food Chem, 48, 491823. https://pubs.acs.org/doi/abs/10.1021/jf9912553

COSGROVE, D. J. (1997). Assembly and enlargement of the primary cell wall in plants. Annu Rev Cell Dev Biol, 13, 171-201. https://doi.org/10.1146/annurev.cellbio.13.1.171

COUTINHO, P. M., HENRISSAT, B. (1999). Carbohydrate-active enzymes: an integrated database approach. In "Recent Advances in Carbohydrate Bioengineering", Gilbert, H. J., Davies, G., Henrissat, B., Svensson, B. Eds. Cambridge: The Royal Society of Chemistry, pp. 3-12.

COUTINHO, P. M., STAM, M., BLANC, E,. HENRISSAT, B. (2003). Why are there so many carbohydrate-active enzyme-related genes in plants? Trends Plant Sci; 8, 563-565. https://doi.org/10.1016/j.tplants.2003.10.002

CROAKA, S., CORREDIG, M. (2006). The role of pectin in orange juice stabilization: effect of pectin methylesterase and pectinase activity on the size of cloud particles. Food Hydrocoll, 20, 961-965. https://doi.org/10.1016/j.foodhyd.2005.10.016

DANG, B. K., HUYNH, T. V, LE, V. V. M. (2012). Simultaneous treatment of acerola mash by ultrasound and pectinase preparation in acerola juice processing: optimization of the pectinase concentration and pectolytic time by response surface methodology. Int Food Res J, 19, 509-513.

DE VRIES, R. P., JANSEN, J., AGUILAR, G., et al. (2002). Expression profiling of pectinolytic genes from Aspergillus niger. FEBS Lett, 530, 41-47. https://doi.org/10.1016/S0014-5793(02)03391-4

DEVI, N. A., RAO, A. G. A. (1996). Fractionation, purification and preliminary characterization of polygalacturonases produced by Aspergillus carbonarius. Enzyme Microb Technol, 18, 59-65. https://doi.org/10.1016/01410229(96)00055-5

DHIMAN, S. S., GARG, G., MAHAJAN, R., GARG, N., SHARMA, J. (2009). Single lay out and mixed lay out enzymatic processes for biobleaching of kraft pulp. Bioresour Technol, 100

4736-4741.

https://doi.org/10.1016/j.biortech.2009.04.059

DI MATTEO, A., GIOVANE, A., RAIOLA, A., CAMARDELlA, L., BONIVENTO, D., DE LORENZO, G., CERVONE, F., BELLINCAMPI, D.
TSERNOGLOU, D. (2005). Structural basis for the interaction between pectin methylesterase and a specific inhibitor protein. Plant Cell, 17, 849-858. https://doi.org/10.1105/tpc.104.028886

DINNELLA, C., LANZARINI, G., STAGNI, A. Palleschi., C. (1994) Immobilization of an endopectin lyase on $\gamma$-alumina: study of factors influencing the biocatalytic matrix stability. J Chem Technol Biotechnol, 59, 237-41. https://doi.org/10.1002/jctb.280590305

DINU, D., NECHIFOR, M. T., STOIAN, G., COSTACHE, M., DINISCHIOTU, A. (2007). Enzymes with new biochemical properties in the pectinolytic complex produced by Aspergillus niger MIUG 16. J Biotechnol, 131, 128-37. https://doi.org/10.1016/j.jbiotec.2007.06.005

DIXIT, V. S., KUMAR, A. R., PANT, A., KHAN, M. I. (2004). Low molecular mass pectate lyase from Fusarium moniliforme: similar modes of chemical and thermal denaturation. Biochem Biophys Res Commun, 315, 477484. https://doi.org/10.1016/j.bbrc.2004.01.083

DOROKHOV, Y. L., MANKINEN, K., FROLOVA, O. Y., MERTIS, A. SAARINEN, J., KALKKINEN, N., et al. (1999). A novel function for ubiquitous plant enzyme pectin methylesterase: the host-cell receptor for the tobacco mosaic virus movement protein. FEBS Lett, 461, 223-228 https://doi.org/10.1016/S0014-5793(99)01447-7

ELYROD, R. P. (1942). The Erwinia - Coliform relationship. J Bacteriol, 44 433-440.

FAVELA-TORRES, E., AGUILAR, C. N., CONTRERAS-ESQUIVEL, J. C. VINIEGRA-GONZÁLEZ, G. (2005). Pectinases. In: Enzyme Technology. A Pandey, C. Webb, C.R. Soccol \& C. Larroche, (Eds.), Asiatech Publishers Inc. ISBN: 8187680121, New Delhi, India, pp. 265-287.

FAVEY, S., BOURSON, C., BERTHEOU, Y., KOTOUJANSKY, A., BOCCORA, M. (1992). Purification of the acidic pectate lyase of Erwinia chrysanthemi 3937 and sequence analysis of the corresponding gene. J Gen Microbiol, 138, 499-508. https://doi.org/10.1099/00221287-138-3-499

FAYYAZ, A., ASBI, B. A., GHAZALI, H. M., CHE MAN, T. B, JINAP, S (1993). Pectinesterase extraction from papaya. Food Chem, 47, 183-185. https://doi.org/10.1016/0308-8146(93)90241-7

FEDERICI, L., CAPRARI, C., MATTEI, B., SAVINO, C., DI MATTEO, A. e al. (2001). Structural requirements of endopolygalacturonase for the interaction with PGIP (polygalacturonase-inhibiting protein), Proc Natl Acad Sci USA, 98 13425-13430. https://doi.org/10.1073/pnas.231473698

FORSTER, H. (1988). Pectinesterase from Phytophthora infestans. Method Enzymol, 161, 355-357. https://doi.org/10.1016/0076-6879(88)61040-8

FRAISSINET-TACHET, L., FEVRE, M. (1996). Regulation by galacturonic acid of pectinolytic enzyme production by Sclerotinia sclerotiorum. Curr Microbiol, 33, 49-53. https://doi.org/10.1007/s002849900073

GAFFE, J., TIZNADO, M. E., HANDA, A. K. (1997). Characterization and functional expression of a ubiquitously expressed tomato pectin methylesterase Plant Physiol, 114(4), 1547-1556. https://doi.org/10.1104/pp.114.4.1547

GAILING, M. F., GUIBERT, A., COMBES, D. (2000). Fractional factoria designs applied to enzymatic sugar beet pulps pressing improvement. Bioprocess Eng, 22, 69-74. https://doi.org/10.1007/PL00009104

GAINVORS, A., FREZIER, V., LEMARESQUIER, H., LEQUART, C., AIGLE M., BELARBI, A. (1994). Detection of polygalacturonase, pectin lyase and pectinesterase activities in Saccharomyces cerevisiae strain. Yeast, 10, 13111319. https://doi.org/10.1002/yea.320101008

GARG, G., SINGH, A., KAUR, A., SINGH, R., KAUR, J., MAHAJAN, R (2016). Microbial pectinases: an ecofriendly tool of nature for industries. 3 Biotech, 6, 47 1-13. https://doi.org/10.1007/s13205-016-0371-4

GARZON, C. G., HOURS, R. A. (1992). Citrus waste: An alternative substrate for pectinase production in solid stage culture. Bioresource Technol, 39, 93-95. https://doi.org/10.1016/0960-8524(92)90061-2

GHILDYAL, N. P., RAMAKRISHNA, S. V., NIRMALA DEVI, P., LONSANE, B. K., ASTHANA, H. N. (1981). Large scale production of pectolytic enzymes by solid state fermentation. J Food Sci Technol, 18, 248-251.

GHORAI, S., BANIK, S. P., VERMA, D., CHOWDHURY, S., MUKHERJEE, S., KHOWALA, S. (2009). Fungal biotechnology in food and feed processing. Food Res Int, 42, 577-587. https://doi.org/10.1016/j.foodres.2009.02.019

GOMES, I., SAHA, R. K., MOHIUDDIN, G., HOQ, M. M. (1992). Isolation and characterization of a cellulase-free pectinolytic and hemicellulolytic thermophilic fungus. World J Microbiol Biotechnol, 8, 589-592. https://doi.org/10.1007/BF01238794

GUMMADI, S. N., PANDA, T. (2003). Purification and biochemical properties of microbial pectinases - a review. Proc Biochem, 38 (7), 987-96 https://doi.org/10.1016/S0032-9592(02)00203-0

GYSLER, C., HARMSEN, J. A. M., KESTER, H. C. M., VISSER, J., HEIM, J. (1990). Isolation and structure of the pectin lyase D-encoding gene from Aspergillus niger, Gene, 89, 101-108. $\quad$ https://doi.org/10.1016/0378 1119(90)90211-9

HADJ-TAIEB, N., AYADI, M., TRIGUI, S., BOUABDOLLAH, F., GARGOURI, A. (2002). Hyper production of pectinase activities by fully constitutive mutant (CT 1) of Penicillium occitanis. Enz Microbial Technol, 30 662-666. https://doi.org/10.1016/S0141-0229(02)00029-7 
HASSAN, B., ALI, S. (2016). A review on biotechnological impact of pectinases in industries. J Sci Res Phar Chem Bio Sci, 1(2), 1-16

HASUNUMA, T., FUKUSAKI, E. I, KOBAYASHI, A. (2003). Methanol production is enhanced by expression of an Aspergillus niger pectin methylesterase in tobacco cells. $J$ Biotechnol, 106, 45-52. https://doi.org/10.1016/j.j.jbiotec.2003.07.008

HATADA, Y., SAITO, K., KOIKE, K., YOSHIMATSU, T., OZAWA, T., KOBAYASHI, T., ITO, S. (2000). Deduced amino-acid sequence and possible catalytic residued of a novel pectate lyase from an alkaliphilic strain of Bacillus. Eur J Biochem, 267, 2268-2275. https://doi.org/10.1046/j.14321327.2000.01243.x

HAYASHI, K., INOUE, Y., SHIGA, M., SATO, S., TAKANO, R., HIRAYAE, K., HIBI, T., HARA, S. (1997). Pectinolytic enzymes from Pseudomonas marginalis MAFF 03-01173. Phytochemistry, 45, 1359-1363. https://doi.org/10.1016/S0031-9422(97)00191-X

HEIKINHEIMO, R., FLEGO, D., PHIRHONEN, M., KARLSSON, M. B. ERIKSSON, A., MAE, KOIV, V., PALVA, E. T. (1995). Characterization of pectate lyase from Erwinia carotovora. Phytopathol, 8, 207-217.

HENRISSAT, B., HEFFRON, S. E., YODER, M. D., LIETZKE, S. E. JURNAK, F. (1995). Functional implications of structure-based sequence alignment of proteins in the extracellular pectate lyase superfamily. Plant Physiol, 107, 963-976. https://doi.org/10.1104/pp.107.3.963

HERRON, S. R., SCAVETTA, R. D., GARRETT, M., LEGNER, M., JURNAK, F. (2003). Characterization and implications of $\mathrm{Ca}^{2+}$ binding to pectate lyase $\mathrm{C}$. $J$ Biol Chem, 278, 12271 12277. Available on line at http://www.jbc.org

HERRON, S. R., BENEN, J. A. E., SCAVETTA, R. D., VISSER, J., JURNAK, F. (2000). Structure and function of pectic enzymes: Virulence factors of plant pathogens, Proc Natl Acad Sci USA, 97, 8762-8769. https://doi.org/10.1073/pnas.97.16.8762

HÖLKER, U., LENZ, J. (2005). Solid-state fermentation - are there any biotechnological advantages? Curr Opin Microbiol, 8, 301-6. https://doi.org/10.1016/j.mib.2005.04.006

HOONDAL, G., TIWARI, R., TEWARI, R., DAHIYA, N., BEG, Q. (2002) Microbial alkaline pectinases and their industrial applications: a review. Appl. Microbiol. Biot, 59(4-5), 409-418. https://doi.org/10.1007/s00253-002-1061-1 HOSSAIN, A. B. M. S., AHMED, S. A., AHMED, M. A., FARIS, M. A. A., ANNUAR, M. S. M., HADEEL, M., NORAH, H. (2011). Bioethanol fuel production from rotten banana as an environmental waste management and sustainable energy. Afr $J \quad$ Microbiol Res, 5(6), 586598. https://doi.org/10.5897/AJMR10.231

HOURS, R. A., VOGET, C. E., ERTOLA, R. J. (1988). Apple pomace as raw material for pectinae production is solid state culture. Biological wastes, 23, 221228. https://doi.org/10.1016/0269-7483(88)90036-5

ICONOMOU, D., ARAPOGLOU, D., ISRAILIDES, C. (2010). Improvement of phenolic antioxidants and quality characteristics of virgin olive oil with the addition of enzymes and nitrogen during olive paste processing. Grasas Aceites, 61, 303-311. https://doi.org/10.3989/gya.064809

IKOTUN,T. (1984). Cell wall degrading enzymes produced by Penicillium

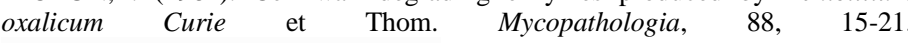
https://doi.org/10.1007/BF00439289

ISHII, T., MATSUNAGA, T. (2001). Pectic polysaccharide rhamnogalacturonan II is covalently linked to homogalacturonan. Phytochemistry, 57(6), 969-974. https://doi.org/10.1016/S0031-9422(01)00047-4

ISSHIKI, A., AKIMITSU, K., YAMAMOTO, M., YAMAMOTO, H. (2001) Endopolygalacturonase is essential for citrus black rot caused by Alternaria citri but not brown spot caused by Alternaria alternata. Mol Plant-Microbe Interact, 14, 749-57. https://doi.org/10.1094/MPMI.2001.14.6.749

JACOB, N., POORNA, A. C., PREMA, P. (2008). Purification and partial characterization of polygalacturonase from Streptomyces lydicus. Bioresour Technol, 99, 6697-701. https://doi.org/10.1016/j.biortech.2007.10.002

JAYANI, R. S., SAXENA, S., GUPTA, R. (2005). Microbial pectinolytic enzymes: A review. Process Biochem, 40, 2931-44. https://doi.org/10.1016/j.procbio.2005.03.026

JEFFRIES, T. W. (1996). Biochemistry and genetics of microbial xylanases, Curr Opin Biotechnol, 7, 337-342. https://doi.org/10.1016/S0958$1669(96) 80041-3$

JIN, D. F., WEST, C. A. (1984). Characteristics of galacturonic acid oligomers as elicitors of casbene synthetase activity in castor bean seedlings. Plant Physiol, 74, 989-992. doi: $10.1104 /$ pp.74.4.989

JOHANSSON, K., AHMAD, M. E., FRIEMANN, R., JO"RNVALL, H., MARKOVI, O., EKLUND, H. (2002). Crystal structure of plant pectin methylesterase. FEBS Lett, 514, 243-249. https://doi.org/10.1016/S0014$\underline{5793(02) 02372-4}$

JUGE, N. (2006). Pant Protein Inhibitors of Cell Wall Degrading Enzymes. Trends Plant Sci, 11, 359-367. https://doi.org/10.1016/j.tplants.2006.05.006

JUNWEI, C., WEIHUA, S., YONG, P., SHUYUN, C. (2000). High producers of Polygalacturonase selected from mutant resistant to Rifampin in alkalophilic Bacillus sp. NTT33. Enzyme Microb. Technol, 27, 545-548. https://doi.org/10.1016/S0141-0229(00)00200-3
KALANTZI, S., MAMMA, D., KALOGERIS, E., KEKOS, D. (2010). Improved properties of cotton fabrics treated with lipase and its combination with pectinase. Fibres Text East Eur, 18, 86-92.

KAPOOR, M., BEG, Q. K., BHUSHAN, B., SINGH, K., DADHICH, K. S. HOONDAL, G. S. (2001). Application of an alkaline and thermostable polygalacturonase from Bacillus sp. MG-cp 2 in degumming of ramie (Boehmeria nivea) and sunn hemp (Crotalaria juncea) bast fibers. Process Biochem, 36, 803-807. https://doi.org/10.1016/S0032-9592(00)00282-X

KARAM, N. E., BELARBI, A. (1995). Detection of polygalacturonase and pectinesterases in lactic acid bacteria. World J Microbiol Biotechnol, 11(5), 559563. https://doi.org/10.1007/BF00286373

KARR, A. L. (1976). Cell wall biogenesis In: Bonner J and Vamer J. E (Eds), Plant Biochmistry, 3rd Edn. Academic Press, New York.

KASHYAP, D. R., CHANDRA, S., KAUL, A., TEWARI, R. (2000). Production, purification and characterization of pectinase from a Bacillus sp. DT7. World Microbiol Biotechnol, 16, 277-82. https://doi.org/10.1023/A:1008902107929 KASHYAP, D. R., VOHRA, P. K., CHOPRA, S., TEWARI, R. (2001). Applications of pectinases in the commercial sector: a review. Bioresour Technol, 77, 215-227. https://doi.org/10.1016/S0960-8524(00)00118-8

KAUR, A., MAHAJAN, R., SINGH, A., GARG, G., SHARMA, J. (2010). Application of cellulase-free xylano-pectinolytic enzymes from the same bacterial isolate in biobleaching of kraft pulp. Bioresour Technol, 101, 91509155. https://doi.org/10.1016/j.biortech.2010.07.020

KAUR, G., KUMAR, S., SATYANARAYANA, T. (2004). Production, characterization and application of a thermostable polygalacturonase of a thermophilic mould Sporotrichum thermophile Apinis. Bioresour Technol, 94(3), 239-43. https://doi.org/10.1016/j.biortech.2003.05.003

KAWANO, C. Y., CHELlEGATTI, M. A. S. C., SAID, S., FONSECA, M. J. V. (1999). Comparative study of intracellular and extracellular pectinases produced by Penicillium frequentans. Biotechnol Appl Biochem, 29, 133-140. https://doi.org/10.1111/j.1470-8744.1999.tb00542.x

KEEN, N. T., DAHLBECK, D., STASKAWICZ, B., BELSER, W. (1984).

Molecular cloning of pectate lyase genes from Erwinia chrysanthemi and their expression in Escherichia coli. J Bacteriol, 159 (3), 825-831.

KESTER, H. C., VISSER, J. (1990). Purification and Characterization of polygalacturonase produced by the fungus, Aspergillus niger. Biotechnol App Biochem, 12, 150-160. https://doi.org/10.1111/j.1470-8744.1990.tb00088.x

KHAN, M., NAKKEERAN, E., KUMAR, S. U. (2013). Potential application of pectinase in developing functional foods. Ann Rev Food Sci Technol, 4, 21-34 https://doi.org/10.1146/annurev-food-030212-182525

KIESENHOFER, D., MACH-AIGNER, A. R., MACH, R. L. (2016) Understandingthe mechanism of carbon catabolite repression to increase protein production in filamentous fungi. In: Schmoll M, Dattenböck C, Eds. Gene Expression Systems in Fungi:Advancements and Applications. Springer International Publishing, pp. 275-288.

KIRK, T. K., JEFFERIES, T. W. (1996). Role of microbial enzymes in pulp and paper processing. In: Jefferies T. W, Viikari L, Editors. Enzymes for pulp and paper processing. ACS symposium series. Washington DC, American Chemical Society, pp. 1-14

KITA, N., BOYD, C. M., GARRETT, M. R., JURNAK, F., KEEN, N. T. (1996). Differential effect of site-directed mutations in pelC on pectate lyase activity, plant tissue maceration, and elicitor activity. J Biol Chem, 271 (43), 2652926535. https://doi.org/10.1074/jbc.271.43.26529

KITAMOTO, N., YOSHINO-YASUDA, S., OHMIYA, K., TSUKAGOSHI, N. (2001). Sequence Analysis and Overexpression of a Pectin Lyase Gene (pel1) from Aspergillus oryzae KBN616. Biosci Biotechnol Biochem, 65(1), 209-212. https://doi.org/10.1271/bbb.65.209

KITTUR, F. S.; KUMAR, A. B. V.; GOWDA, L. R.; THARANATHAN, R. N. (2003). Chitosanolysis by a pectinase isozyme of Aspergillus niger - a nonSpecific activity. Carbohydrate Polymers, 53, 191-196. https://doi.org/10.1016/S0144-8617(03)00042-0

KLUG-SANTNER, B. G., SCHNITZHOFER, W., VRSANSKÁ, M., ET AL. (2006). Purification and characterization of a new bioscouring pectate lyase from Bacillus pumilus BK2. J Biotechnol, 121, 390-401. https://doi.org/10.1016/j.jbiotec.2005.07.019

KOBOYASHI, T., HIGAKI, N., YAJIMA, N., SUZUMATSU, A., HAGHIHARA, H., KAWAI, S. et al. (2001). Purification and properties of a galacturonic acidreleasing exopolygalacturonase from a strain of Bacillus. Biosci Biotechnol Biochem, 65, 842-847. https://doi.org/10.1271/bbb.65.842

KRAULIS, P. J. (199!). MOLSCRIPT: A program to produce both detailed and schematic plots of protein structures. J Appl Crystallography, 24(5), 946-950. https://doi.org/10.1107/S0021889891004399

KUBRA, K. T., ALI, S., WALAIT, M., SUNDUS, H. (2018). Potential applications of pectinases in food, agricultural and environmental sectors. $J$ Pharm Chem Biol Sci, 6(2), 23-34. Online available at https://www.jpcbs.info KUSTERS-VAN SOMEREN, M. A., HARMSEN, J. A. M., KESTER, H. C. M., VISSER, J. (1991). Structure of the Aspergillus niger pelA gene and its expression in Aspergillus niger and Aspergillus nidulans. Curr Genet, 20(4), 293-299. https://doi.org/10.1007/BF00318518 
KUSTERS-VAN SOMEREN, M., FLIPPHI, M., DE GRAAFF, L., VAN DEN BROECK, H., KESTER, H. C. M., HINNEN, A., VISSER, J. (1992). Characterization of the Aspergillus niger pelB gene: structure and regulation of $\begin{array}{lc}\text { expression. } M o l & \text { Gen } \\ \text { https://doi.org/10.1007/BF00272352 }\end{array}$ KUTATELADZE, L., JABOVA, M., KHVEDELIDZE, R. (2009). Selection of microscopic fungi-Pectinase producers. Bull Georg Natl Acad Sci, 3(1), 136-142. LANDBO, A. K., KAACK, K., MEYER, A. S. (2007). Statistically designed two step response surface optimization of enzymatic prepress treatment to increase juice yield and lower turbidity of elderberry juice. Innovative Food Science and Emerging Technologies, https://doi.org/10.1016/j.ifset.2006.08.006

LANG, C., DÖRNENBURG, H. (2000). Perspectives in the biological function and the technological application of polygalacturonases. Appl Microbiol Biotechnol, 53, 366-75. doi: https://doi.org/10.1007/s002530051628

LARA-MÁRQUEZ, A., ZAVALA-PÁRAMO, M. G., LÓPEZ-ROMERO, E. CAMACHO, H. C. (2011). Biotechnological potential of pectinolytic complexes of fungi. Biotechnol Lett, 33, 859-868. doi: https://doi.org/10.1007/s10529. 011-0520-0

LE GOFF, A., RENARD, C. M. G. C., BONNIN, E., THIBAULT, J. F. (2001) Extraction, purification and chemical characterisation of xylogalacturonans from pea hulls. Carbohydr Polym, 45(4), 325-334. https://doi.org/10.1016/S01448617(00)00271-X

LIAO, C. H., GAFFNEY, T. D., BRADLEY, S. P., WONG, L. C. (1996) Cloning of pectate lyase gene from Xanthomonas campestris pv. Malvacearum and comparison of its sequence relationship with pel gene of soft rot Erwinia and Pseudomonas. Mol Plant Microb Interaction, 1, 14-21. https://doi.org/10.1094/MPMI-9-0014

LIBKIND, D., PE'REZ, P., SOMMARUGA, R., DIÉGUEZ, M. C., FERRARO, M., BRIZZIO, S., ZAGARESE, H., VAN BROOCK, M. (2004). Constitutive and UV-inducible synthesis of photoprotective compounds (carotenoids and mycosporines) by freshwater yeasts. Photochem Photobiol Sci, 3, 281-286. http://dx.doi.org/10.1039/B310608J

LIETZKE, S. E., YODER, M. D., KEEN, N. T., JURNAK, F. (1994). The threedimensional structure of pectate lyase $\mathrm{E}$, a plant virulence factor from $E$. chrysanthemi. Plant Physiol, 106, 849-862. https://doi.org/10.1104/pp.106.3.849

LIMA, J. O., PEREIRA, J. F., DE ARAÚJO, E. F., DE QUEIROZ, M. V. (2017). Pectin lyase overproduction by Penicillium griseoroseummutant resistant to catabolite repression. Brazilian J Microbiol, 48(3). 602-660. https://doi.org/10.1016/j.bjm.2016.12.009

LONSANE, B. K., GHILDYAL, N. P., BUDIATMAN, S., RAMAKRISHNA, S. V. (1985). Engineering aspects of solid-state fermentation. Enzyme Microb Technol, 7, 258-265. https://doi.org/10.1016/0141-0229(85)90083-3

MAKKY, E. A, YUSOFF, M. M. (2015). Bioeconomy: pectinases purification and application of fermented waste from Thermomyces lanuginosus. $J \mathrm{Med}$ Bioeng, 4(1), 76-80. https://doi.org/10.12720/jomb.4.1.76-80

MALDONADO, M. C., SAAD, A. M. S., CALLIERI, D. A. S. (1994) Purification and characterization of pectinesterase produced by a strain of Aspergillus niger. Curr Microbiol, 28, 193-196. https://doi.org/10.1007/BF01575960

MALDONALDO, M. S., SAAD, A. M. S. (1998). Production of pectinesterase and polygalacturonase by Aspergillus niger in submerged and solid state systems. J Ind Microbiol Biotechnol, 20, 34-38. https://doi.org/10.1038/sj..jim.2900470 MARIMUTHU, S., SENTHILKUMAR, R. S., BALASUBRAMANIAN, S., RAJKUMAR, R., CHRISTIE, S. A. (2000). Effect of addition of biopectinase on biochemical composition of CTC black tea. In Recent Advances in Plantation Crops Research, pp. 265-269.

MAYANS, O., SCOTT, M., CONNERTON, I., GRAVESEN, T., BENEN, J. VISSER, J., PICKERSGILL, R., JENKINS, J. (1997). Two crystal structures of pectin lyase A from Aspergillus reveal a $\mathrm{pH}$ driven conformational change and striking divergence in the substrate binding clefts of pectin and pectate lyases. Structure, 5, 677- 689. http://biomednet.com/elecref/0969212600500677 MCMILLAN, G. P., JOHNSTON, D. J. PEROMBELON, M. C. M. (1992) Purification of homogeneity extracellular polygalacturonase and isoenzymes of pectate lyase of Erwinia carotovora sub sp. Atroseptica by column chromatography. J Appl Bacteriol, 73, 83-86. https://doi.org/10.1111/j.13652672.1992.tb04974.x

MCNEIL, M., DARVILL, A. G, FRY, S. C., ALBERSHEIM, P. (1984) Structure and function of the primary cell walls of plants. Ann Rev Biochem, 53(1), 625-663. https://doi.org/10.1146/annurev.bi.53.070184.003205

MEHTA, A., CHOPRA, S., KARE, V., MEHTA, P. (1992). Influence of active carbon sources on the production of pectolytic and cellulolytic enzymes by Fusarium oxysporum and Fusarium moniliforme. Zentralblatt fur Mikrobiologie, 147, 557-561. https://doi.org/10.1016/S0232-4393(11)80387-2

MILLER, N. J., RICE-EVANS, C. A. (1997). The relative contributions of ascorbic acid and phenolic antioxidants to the total antioxidant activity of orange and apple fruit juices and blackcurrant drink. Food Chem, 60, 331-337. https://doi.org/10.1016/S0308-8146(96)00339-1
MINJARES-CARRANCO, A., TREJO-AGUILAR, B. A., AGUILAR, G., VINIEGRA-GONZÁLEZ， G. (1997). Physiological comparison between pectinase-producing mutants of Aspergillus niger adapted either to solid-state fermentation or submerged fermentation. Enzyme Microb Technol, 21, 25-31. https://doi.org/10.1016/S0141-0229(96)00212-8

MIYAZAKI, Y. (1991). Purification and characterization of an endo-pectate lyase from Bacillus macerans. Agric Biol Chem, 55, 23-30. https://doi.org/10.1080/00021369.1991.10870530

MOHARIB, S. A., EL-SAYED, S. T., JWANNY, E. W. (2000). Evaluation of enzymes produced from yeast Nahrung 44, 47-51. https://doi.org/10.1002/(SICI)1521-3803(20000101)44:1<47::AIDFOOD47>3.0.CO;2-K

MORRIS, G. A., KÖK, S. M., HARDING, S. E., ADAMS, G. G. (2010) Polysaccharide drug delivery systems based on pectin and chitosan Biotechnology \& Genetic Engineering Reviews, 27, 257-284. https://doi.org/10.1080/02648725.2010.10648153

MUKADAM, D. S., CHAVAN, A. M., TAWARE, A. S., TAWARE, S. D. (2010). Isolation, cloning and molecular characterization of polygalacturonase I ( $\mathrm{ggaI}$ ) gene from Aspergillus niger isolate from mango. Indian J Biotechnol, 9, 153-159.

MURTHY, P. S., NAIDU, M. M. (2011). Improvement of robusta coffee fermentation with microbial enzymes. Eur J Appl Sci, 3, 130-139.

MUTTER, M., BELDMAN, G., SCHOLS, H. A., VORAGEN, A. G. J. (1994) Rhamnogalacturonan $\alpha$-L-Rhamnopyranohydrolase: a novel enzyme specific for the terminal nonreducing rhamnosyl unit in rhamnogalacturonan regions of pectin. Plant Physiol, 106, 241-50. https://doi.org/10.1104/pp.106.1.241

MUTTER, M., COLQUHOUN, I. J., SCHOLS, H. A., BELDMAN, G., VORAGEN, A. G. J. (1996). Rhamnogalacturonase B from Aspergillus aculeatus is a rhamnogalacturonan $\alpha$ - $\mathrm{L}$ rhamnopyranosyl-(1-4)- $\alpha$-D galactopyranosyluronide lyase. Plant Physiol, 110, 73-77. https://doi.org/10.1104/pp.110.1.73

MUTTER, M., RENARD, C. M. G. C., BELDMAN, G., SCHOLS, H. A., VORAGEN, A. G. J. (1998). Mode of action of RG-hydrolase and RG-lyase toward rhamnogalacturonan oligomers: characterization of degradation products using RG-rhamnohydrolase and RG-galacturonohydrolase. Carbohydr Res, 311, 155-64. https://doi.org/10.1016/S0008-6215(98)00188-8

NAGAI, M., KATSURAGI, T., TERASHITA, T., YOSHIKAWA, K., SAKAI, T. (2000). Purification and characterization of an endo-polygalacturonase from Aspergillus awamori. Biosci Biotechnol Biochem, 64, 1729-32. https://doi.org/10.1271/bbb.64.1729

NIERMAN, W. C., PAIN, A., ANDERSON, M. J., WORTMAN, J. R., KIM, H. S., et al. (2005). Genomic sequence of the pathogenic and allergenic filamentous fungus Aspergillus fumigatus. Nature (London), 438, 1151-1156. https://doi.org/10.1038/nature04332

O'NEILL, M. A., EBERHARD, S., ALBERSHEIM, P., DARVILL, A. G. (2001). Requirement of borate cross-linking of cell wall rhamnogalacturonan II for Arabidopsis growth. Science, 294, 846-849. https://doi.org/10.1126/science.1062319

OSLEN, H. S. (2013). Enzymes at work- A concise guide to industrial enzymes and their use. 4th edition, Final editing: Damhus, T., Kaasgaard, S., Olsen, H. S. Novozymes A/S Bagsvaerd, Denmark, pp. 76.

PAGES, S., HEIJNE, W. H., KESTER, H. C., VISSER, J., BENEN, J. A. (2000). Subsite mapping of Aspergillus niger endopolygalacturonase II by site-directed mutagenesis. J Biol Chem, 275, 29348-29353. https://doi.org/10.1074/jbc.M910112199

PALANIVELU, P. (2006). Polygalacturonases: Active site analyses and mechanism of action. Indian J Biotechnol, 5, 148-162.

PARENICOVÁ, L., BENEN, J. A., KESTER, H. C., VISSER, J. (2000). pgaA and pgaB encode two constitutively expressed endopolygalacturonases of Aspergillus niger. Biochem J, 345(3), 637-644. https://doi.org/10.1042/02646021:3450637

PASHA, M. K., ANURADHA, P., SUBBARAO, D. (2013). Applications of Pectinases in Industrial Sector. Int J Pure Appl Sci Technol, 16(1), 89-95. www.ijopaasat.in

PATHAK, N., SANWAL, G. G. (1998). Multiple forms of polygalacturonase from banana fruits. Phytochemistry, 48, 249-255. https://doi.org/10.1016/S0031-9422(98)00005-3

PATHAK, P., BHARDWAJ, N. K., SINGH, A. K. (2010). Enzymatic deinking of office waste paper: an overview. Ippta J, 22, 83-88.

PEDROLLI, D. B., GOMES, E. MONTI, R., CARMONA, E. C. (2008). Studies on productivity and characterization of polygalacturonase from Aspergillus giganteus submerged culture using citrus pectin and orange waste. Appl Biochem Biotechnol, 144(2), 191-200. https://doi.org/10.1007/s12010-007-8059-1 PEDROLLI, D. B., MONTEIRO, A. C., GOMES, E., CARMONA1, E. C (2009). Pectin and Pectinases: Production, Characterization and Industria Application of Microbial Pectinolytic Enzymes. The Open Biotechnol J, 3, 9-18. https://doi.org/10.2174/1874070700903010009

PEL, H. J., DE WINDE, J. H., ARCHER, D. B., DYER, P. S., HOFMANN, G. et al. (2007). Genome sequencing and analysis of the versatile cell factory Aspergillus niger. Nat Biotechnol, 25, 221-231. https://doi.org/10.1038/nbt1282 
PETERSEN, S. (2001). Enzymes to upgrade plant nutrients. Feed Mix, 9, 12-15. PETERSEN, T. N., KAUPPINEN, S., LARSEN, S. (1997). The crystal structure of a rhamnogalacturonase A from Aspergillus aculeatus: a right-handed paralle beta helix. Structure, 5, 533-544. https://doi.org/10.1016/S09692126(97)00209-8

PHUTELA, U., DHUNA, V., SHANDU, S., CHANDHA, B. S. (2005). Pectinase production by a Thermophilic Aspergillus fumigatus isolated from decomposting orange peels. Brazilian J Microbiol, 36, 63-69. http://dx.doi.org/10.1590/S1517. 83822005000100013

PICKERGILL, R., SMITH, D., WORBOYS, K., JENKINS, J. (1998). Crystal structure of polygalacturonase from Erwinia carotovora subsp. Carotovora. $J$ Biol Chem, 273, 24660-24664.https://doi.org/10.1074/jbc.273.38.24660

PICKERSGILL, R., JENKINS, J., HARRIS, G., NASSER, W., ROBERTBAUDOUY, J. (1994). The structure of Bacillus subtilis pectate lyase in complex with calcium. Nat Struct Biol, 1, 717-723.

PIETRO, A. D., RONCERO, M. I. G. (1996). Purification and characterization of an exo polygalacturonase from the tomato vascular wilt pathogen Fusarium oxysporum f.sp. lycopersici. FEMS Microbiol Lett, 145, 295-9. https://doi.org/10.1111/j.1574-6968.1996.tb08592.x

PITKÄNEN, K., HEIKINHEIMO, R., PAKKANEN, R. (1992). Purification and characterization of Erwinia chrysatnthemi B374 pectin methylesterase produced by Bacillus subtilis. Enzyme Microbial Technol, 14, 832-6. https://doi.org/10.1016/0141-0229(92)90100-3

PITT, D. (1988). Pectin Lyase from Fhoma medicaginis var. pinodella. Methods Enzymol, 161, 350-354. https://doi.org/10.1016/0076-6879(88)61039-1

PRAVEEN, K. G., SUNEETHA, V. (2014). A cocktail enzyme-pectinase from fruit industrial dump sites: a review. Res J Pharm Biol Chem Sci, 5(2), 12521258.

RAJULAPATI, V., SHARMA, K., DHILLON, A., GOYAL, A. (2018). SAXS and homology modelling based structure characterization of pectin methylesterase a family 8 carbohydrate esterase from Clostridium thermocellum ATCC 27405. Archives of Biochemistry and Biophysics, 641, 39-49. https://doi.org/10.1016/j.abb.2018.01.015

RAO, N. M., KEMBHAVI, A. A., PANT, A. (1996). Implication of tryptophan and histidine in the active site of endopolygalacturonase from Aspergillus ustus: Elucidation of reaction mechanism. Biochim Biophys Acta, 1296, 167-173. https://doi.org/10.1016/0167-4838(96)00067-2

REID, RICARD, M. (2000). Pectinase in paper making: Solving retention problems in mechanical pulp, bleached with hydrogen peroxide, Enz. Microbiol, Technol, 26, 115-123. https://doi.org/10.1016/S0141-0229(99)00131-3

REVILLA, I., GANZÁLEZ-SAN JOSÉ, M. L. (1998). Methanol release during fermentation of red grapes treated with pectolytic enzymes. Food Chem, 63, 307312. https://doi.org/10.1016/S0308-8146(98)00049-1

REVILLA, I., GANZÁLEZ-SAN JOSÉ, M. L. (2003). Addition of pectolytic enzymes: an enological practice which improves the chromaticity and stability of red wines. Int J Food Sci Technol, 38, 29-36. https://doi.org/10.1046/j.13652621.2003.00628.x

RIBEIRO, D. S., HENRIQUE, S., OLIVEIRA, L. S., MACEDO, G. A., FLEURI, L. F. (2010). Enzymes in juice processing: a review. Inter J Food Sci Tech, 45(4), 635-641. https://doi.org/10.1111/j.1365-2621.2010.02177.x

RIDLEY, B. L., O'NEILL, M. A., MOHNEN, D. (2001). Pectins: structure, biosynthesis, and oligogalacturonide-related signaling. Phytochemistry, 57(6), 929-67. https://doi.org/10.1016/S0031-9422(01)00113-3

ROMBOUTS, F. M., PILNIK, W. (1980). Pectic enzymes. In: Rose A. H., Ed Microbial Enzymes and Bioconversions. Academic Press, London, 5, 227-72.

SAKAI, T., SAKAMOTO, T., HALlAERT, J., VANDAMME, E. (1993). Pectin, pectinase and protopectinase: production, properties and applications. $A d v$ Appl Microbiol, 39, 213-94. https://doi.org/10.1016/S0065-2164(08)70597-5 SAKIYAMA, C. C. H., PAUlA, E. M., PEREIRA, P. C., BORGES, A. C. SILVA, D. O. (2001). Characterization of pectin lyase produced by an endophytic strain isolated from coffee cherries. Lett Appl Microbiol, 33, 117121. https://doi.org/10.1046/j.1472-765x.2001.00961.x

SALAZAR, L., JAYASINGHE, U. (1999). Fundamentals of purification of plant viruses, In: Techniques in Plant, C.I.P. Virology, J.O. Training Manual, Virus Purification, Section 5.1 International Potato Centre, Peru.

SAPUNOVA, L. I., MIKHAILOVA, R. V., LOBANOK, A. G. (1995). Properties of pectin lyase preparations from the genus Penicillium. Appl Microbiol Biochem, 31, 435-8.

SARANRAJ, P., NAIDU, M. A. (2014). Microbial Pectinases: A Review. Global J Trad Med Sys, 3(1), 1 - 9 .

SATHYA, G., NAIDU, N., PANDA, T. (1998). Application of response surface methodology to evaluate some aspects of pectolytic enzymes from Aspergillus niger. Biochem Eng J, 2, 71-77. https://doi.org/10.1016/S1369-703X(98)000199

SATHYA, G., NAIDU, N., PANDA, T. (1999). Performance of pectolytic enzymes during hydrolysis of pectic substances under assay conditions: a statistical approach. Enzyme Microb Technol, 25, 116-124. https://doi.org/10.1016/S0141-0229(99)00017-4
SATHYA, G., NAIDU, N., PANDA, T. (2003). Studies on pH and thermal deactivation of pectolytic enzymes from Aspergillus niger. Biochem Eng J, 16, 57-67. https://doi.org/10.1016/S1369-703X(03)00022-6

SCHELL, M. A., DENNY, T. P., HUANG, J. (1994). Extracellular virulence factors of Pseudomonas solanacearum: role in disease and their regulation. In: Kado C. I, Crosa J. H (Eds) Molecular mechanisms of bacterial virulence. Kluwer, Dordrecht, pp. 311-324.

SCHNITZHOFER, W., WEBER, H. J., VRŠANSKÁ, M., BIELY, P., CAVACO-PAULO, A., GUEBITZ, G. M. (2007). Purification and mechanistic characterisation of two polygalacturonases from Sclerotium rolfsii. Enzyme Microb Technol, 40

1739-1747.

SCHOLS, H. A., GERAEDS, C. C. J. M., SEARLE-VAN LEEUWEN, M. F., KORMELINK, F. J. M., VORAGEN, A. G. J. (1990). Rhamnogalacturonase: a novel enzyme that degrades the hairy regions of pectins. Carbohydr Res, 206, 105-115. https://doi.org/10.1016/0008-6215(90)84010-R

SCHOLS, H. A., VISSER, R. G. F., VORAGEN, A. G. J. (2009). Pectin and Pectinases. Wagenigen Academic Publishers, Wagenigen, Netherlands, ISBN 978-90-8686-677-9.

SCHROTER, K. H., ARKEMA, A., KESTER, H. C. M., VISSER, J., DIJKSTRA, B. W. (1994). Crystallographic and preliminary crystallographic charecterization of endopolygalacturonase II form Aspergillus niger. J Mol Biol, 243, 351-352. https://doi.org/10.1006/jmbi.1994.1660

SELINGER, L. B., FORSBERG, C. W., CHENG, K. J. (199). The rumen: a unique source of enzyme for enhancing livestock production. Anaerobe, 2, 236284. https://doi.org/10.1006/anae.1996.0036

SEMENOVA, M. V., GRISHUTIN, S. G., GUSAKOV, A. V., OKUNEV, O. N., SINITSYU, A. P. (2003). Isolation and properties of pectinases from the fungus Aspergillus japonicus. Biochem (Mosc), 68, 559-569. https://doi.org/10.1023/A:1023959727067

SENTHILKUMAR, R. S., SWAMINATHAN, K., MARIMUTHU, S. RAJKUMAR, R. (2000). Microbial enzymes for processing of tea leaf. In: Muraleedharan N, Kumar R. R, Fditors. Recent Adv Plant Crops Res. India, Allied publishers limited, pp. 265-269.

SERVILI, M., BEGLIOMINI, A. L., MONTEDORO, G., PETRUCCIOLI, M. FEDERICI, F. (1992). Utilisation of a yeast pectinase in olive oil extraction and red wine making processes. $J$ Sci Food Agric, 58, 253-260. https://doi.org/10.1002/jsfa.2740580214

SHARMA, A., SHRIVASTAVA, A., SHARMA, S., GUPTA, R., KUHAD, R. C. (2013a). Microbial pectinase and their application. In: Singh A (Ed) Kuhad R.C. Biotechnology for environmental management and resource recovery, Springer Science and Business Media, pp. 107-124.

SHARMA, H. S. S., ROBINSON, E. (1983). Fungal colonization during glyphosate induced desiccation and dew-retting of flax cultivars. Technical report no. 2281.11

SHARMA, N., RATHORE, M., SHARMA, M. (2012). Microbial pectinase: sources, characterization and applications. Rev Environ Sci Biotechnol. doi 10.1007/s11157-012-9276-9,

https://www.researchgate.net/publication/257657886

SHARMA, N., RATHORE, M., SHARMA, M. (2013b). Microbial pectinase: sources, characterization and applications. Rev Environ Sci Biotechnol, 12, 4560. https://doi.org/10.1007/s11157-012-9276-9

SHEVCHIK, V. E., HUGOUVIEUX-COTTE-PATTAT, N. (1997) Identification of a bacterial pectin acetyl esterase in Erwinia chysanthemi 3937 Mol Microbiol, 24(6), 1285-1301. https://doi.org/10.1046/j.13652958.1997.4331800.x

SHIMIZU, T., NAKATSU, T., MIYAIRI, K., OKUNO, T., KATO, H. (2002). Active-site architecture of endopolygalacturonase I from Stereum purpureum revealed by crystal structures in native and ligand-bound forms at atomic resolution. Biochem, 41, 6651-6659. https://doi.org/10.1021/bi025541a

SILVA, D., MARTINS, E. S., SILVA, R., GOMES, E. (2002). Pectinase production by Penicillium viridicatum RFC3 by solid state fermentation using agricultural wastes and agro-industrial by-products. Braz J Microbiol, 33, 31824. http://dx.doi.org/10.1590/S1517-83822002000400008

SINGH, S. A., APPURAO, A. G. (1989). A simple fractionation protocol for and a comprehensive study of the molecular properties of two major endopolygalacturonases from Aspergillus niger. Biotechnol Appl Biochem, 35, 115-123. https://doi.org/10.1042/BA20010077

SINGH, S. A., PLATTNER, H., DIEKMANN, H. (1999). Exo polygalacturonate lyase from a thermophilic Bacillus sp. Enzyme Microbial Technol, 25, 420-425. https://doi.org/10.1016/S0141-0229(99)00066-6

SINGH, S. A., RAO, A. G. A. (2002). A simple fractionation protocol for, and a comprehensive study of the molecular properties of two major endopolygalacturonases from Aspergillus niger. Biotechnol Appl Biochem, 35 115-123. https://doi.org/10.1042/BA20010077

SINGH, S., GUPTA, R. (2004). Apple juice clarification using fungal pectinolytic enzyme and gelatin. Indian J Biotechnol, 3, 573-576.

SITTIDILOKRATNA, C., CHITRADON, L., PUNSUVON, V., SIRIACHA, P. (2007). Screening of pectinase producing bacteria and their efficiency in biopulping of paper mulberry bark. Science Asia, 33, 131-135. 
SMITH, J. E., AIDOO, K. E. (1988). Growth of fungi on Solid Substrates. Physiology of Industrial Fungi, Ed. Berry, D. R. Blackwell, Oxford, England, pp. 249-269.

SOARES, M. M. C. N., DA SILVA. R., CARMONA, E. C., GOMES, E. (2001) Pectinolytic enzyme production by Bacillus species and their potential application on juice extraction. W J Microbiol Biotechnol, 17, 79-82. https://doi.org/10.1023/A:1016667930174

SOARES, M., DA SILVA, R., GOMES, E. (1999). Screening of bacterial strains for pectinolytic activity: Characterization of the polygaluctrunodase produced by Bacillus sp. Revista de Microbiologia, 30, 299-303. http://dx.doi.org/10.1590/S0001-37141999000400002

SORESEN, S. O., PAULY, M., BUSH, M., SKJOT, M., MCCANN, M. C., BORKHARDT, B., ULVOSKOV, P. (2000). Pectin engineering: modification of potato pectin by in vivo expression of endo-1,4- $\beta$-D-galacturonase. Proc Natl Acad Sci USA, 97, 7639-7644. https://doi.org/10.1073/pnas.130568297

SORIANO, M., DIAZ, P., PASTOR, F. I. J. (2005). Pectinolytic systems of two aerobic sporogenous bacterial strains with high activity on pectin. Curr Microbiol, 50(2), 114-118. https://doi.org/10.1007/s00284-004-4382-8 SULAIMAN, M. Z., SULAIMAN, N. M., LIEW, S. Y. (1998). Limiting permeate flux in the clarification of untreated starfruit juice by membrane ultrafiltration. Chemical Engineering Journal, 69(2), 145-148. https://doi.org/10.1016/S1385-8947(98)00062-X

SUNEETHA, V., PRATHYUSHA, K. (2011). Bacterial pectinases and their potent biotechnological application in fruit processing/juice production industry: a review. $J$ Phytol, 3(6), 11-15.

TAKAO, M., NAKANIWA, T., YOSHIKAWA, K., TERASHITA, T., SAKAI, T. (2000). Purification and characterization of thermostable pectate lyase with protopectinase activity from thermophilic Bacillus sp. TS 47. Biosci Biotechnol Biochem, 64, 2360-7. https://doi.org/10.1271/bbb.64.2360

TANABE, H., KOBAYASHI, Y., AKAMATSU, I. (1986). Pretreatment of pectic wastewater from orange canning by soft-rot Erwinia carotovora. $J$ Fermentation Technol, 64, 265-268. https://doi.org/10.1016/03856380(86)90110-X

TANABE, H., YOSHIHARA, K., TAMURA, K., KOBAYASHI, Y. AKAMATSU, I., NIYOMWAN, N., FOOTRAKUL, P. (1987). Pretreatment of pectic wastewater from orange canning process by an alkalophilic Bacillus sp. $J$ Fermentation Technol, 65, 243-246. https://doi.org/10.1016/03856380(87)90173-7

TAO, B. Y., REILLY, P. J., ROBYT, J. F., (1987). Detection of covalent intermediate in the mechanism of porcine pancreatic $\alpha$-amylase by using ${ }^{13} \mathrm{C}$ nuclear magnetic resonance. Biochim Biophys Acta, 995, 214-220. https://doi.org/10.1016/0167-4838(89)90038-1

THAKUR, B. R., SINGH, R..K. HANDA, A. K. (1997). Chemistry and uses of pectin: a review. Critical Reviews in Food Science and Nutrition, 37, 47-73. https://doi.org/10.1080/10408399709527767

THOMAS, L. M., DOAN, C. N., OLIVER, R. L., YODER, M. D. (2002) Structure of pectate lyase A: comparison to other isoforms. Acta Crystallogr D, 58, 1008-1015. https://doi.org/10.1107/S0907444902005851

TOCHI, B. N., WANG, Z., XU, S. Y, ZHANG, W. (2009). The Influence of a pectinase and pectinase/hemicellulases enzyme preparations on percentage pineapple juice recovery, particulates and sensory attributes. Pak J Nutrition, 8 , 1184-1189. https://doi.org/10.3923/pjn.2009.1184.1189

TREJO-HERNANDEZ, M. R., ORIOL, E., LOPEZ-CANALES, A., ROUSSOS S., VINIEGRA, G., RAIMBAULT, M. (1991). Production of pectinases by Aspergillus niger by solid state fermentation on support. Micol Neotrop Apl, 4, 49:62.

TRUONG, L. V., TUYEN, H., HELMKE, E., BINH, L. T., SCHWEDER, T. (2001). Cloning of two pectate lyase genes from the marine Antarctic bacterium Pseudoalteromonas haloplanktis strain ANT/505 and characterization of the enzymes. Extremophiles, 5, 35-44. https://doi.org/10.1007/s007920000170

TUCKER, G. A., WOODS, L. F. J. (1991). Enzymes in production of Beverages and Fruit juices. Enzymes in Food Processing, Blackie, New York, pp. 201-203.

VAILLANT, F., MILLAN, A., DORNIER, M., DECLOUX, M. REYNES, M. (2001). Strategy for economical optimisation of the clarification of pulpy fruit juices using crossflow microfiltration. $J$ Food Eng, 48, 83-90. http://dx.doi.org/10.1016/S0260-8774(00)00152-7

VAN ALEBEEK, G. J. W. M., CHRISTENSEN, T. M. I. E., SCHOLS, H. E., MIKKELSEN, J. D., VORAGEN, A. G. J. (2002). Mode of action of pectin lyase A of Aspergillus niger on differently C6-substituted oligogalacturonides. J Biol Chem, 277(29), 25929-36. https://doi.org/10.1074/jbc.M202250200

VAN DER MAAREL, M. J. E. C., VAN DER VEEN, B., UITDEHAAG, J. C. M., LEEMHUIS, H., DIJKHUIZEN, L. (2002). Properties and applications of starch-converting enzymes of the $\alpha$-amylase family. J Biotechnol, 94, 137-155. https://doi.org/10.1016/S0168-1656(01)00407-2

VAN POUDEROYEN, G., SNIJDER, H. J., BENEN, J. A., DIJKSTRA, B. W. (2003). Structural insights into the processivity of endopolygalacturonase I from Aspergillus niger. FEBS Lett, 554, 462-466. https://doi.org/10.1016/S00145793(03)01221-3

VAN SANTEN, Y., BENEN, J. A. E., SCHROTER, K. H., KALK, K. H., ARMAND, S., et al. (1999). 1.68-Á Crystal structure of endopolygalacturonase
II from Aspergillus niger and identification of active site residues by site-directed $\begin{array}{lllll}\text { mutagenesis. } J \text { Biol } & \text { Chem, } & \text { 274, } 30474-33480 .\end{array}$ https://doi.org/10.1074/jbc.274.43.30474

VERSARI, A., BIESENBRUCH, S., BARBANTI, D., FARNELL, P. J., GALASSI, S. (1997). Effects of pectolytic enzymes on selected phenolic compounds in strawberry and raspberry juices. Food Res Int, 30, 811-817. https://doi.org/10.1016/S0963-9969(98)00050-7

VIIKARI, L., TENKANEN, M., SUURNAKKI, A. (2001). Biotechnology in the pulp and paper industry. In: Rehm HJ (Ed) Biotechnology. Wiley, Hoboken, pp. 523-546.

VITALI, J., SCHICK, B., KESTER, H. C. M., VISSER, J., JURNAK, F. (1998). The tree dimensional structure of Aspergillus niger pectin lyase B at 1.7- $\AA$ resolution. Plant Physiol, 116(1), 69-80. https://doi.org/10.1104/pp.116.1.69 VORAGEN, A, G. J., COENEN GERD-JAN, VERHOEF, R. P., SCHOLS, H. A. (2009). Pectin, a versatile polysaccharide present in plant cell walls. Struct Chem, 20(2), 263-275. https://doi.org/10.1007/s11224-009-9442-z

WALKINSHAW, M. D., ARNOTT, S. (1981a). Conformations and interactions of pectins. I. X ray diffraction analysis of sodium pectate in neutral acidified forms. $J \mathrm{Mol}$ Biol, 153, 1055-1073. https://doi.org/10.1016/00222836(81)90467-8

WALKINSHAW, M. D., ARNOTT, S. (1981b). Conformations and interactions of pectins. II. Models of junction zones in pectinic acid and calcium pectate gels. J Mol Biol, 153, 1075-1108. https://doi.org/10.1016/0022-2836(81)90468-X

WANG, Q., FAN, X., HUA, Z., GAO, W., CHEN, J. (2007). Influence of combined enzymatic treatment on one-bath scouring of cotton knitted fabrics. Biocat Biotrans, 25, 9-15. https://doi.org/10.1080/10242420601143057 WILLATS, W. G. T., KNOX, P., MIKKELSEN, J. D. (2006). Pectin: new insights into an old polymer are starting to gel. Trends Food Sci Technol, 17, 97104. https://doi.org/10.1016/j.tifs.2005.10.008

XIAO, J., LU, F. P., LI, Y., LI, J. T. (2012). Expression and Bioinformatics Analysis of Pectate Lyase Gene from Bacillus subtilis 521. Physics Procedia, 33, 872-876. https://doi.org/10.1016/j.phpro.2012.05.148

XU, Q. H., WANG, Y. P., QIN, M. H., FU, Y. J., LI, Z. Q., ZHANG, F. S., LI, J. H. (2011). Fibre surface characterization of old newprint pulp deinked by combining hemicellulase with laccase-mediated system. Bioresour Technol, 102, 6536-6540. https://doi.org/10.1016/j.biortech.2011.03.051

XU, Q., FU, Y., GAO, Y., QIN, M. (2009). Performance and efficiency of old newspaper deinking by combining cellulase/hemicellulase with laccase-violuric $\begin{array}{llll}\text { acid } & \text { system. Waste } & \text { Manag, } & \text { 29, }\end{array}$ https://doi.org/10.1016/j.wasman.2008.10.007

YADAV, P. K., SINGH, V. K., YADAV, S., YADAV, K. D. S., YADAV, D. (2009). In silico Analysis of Pectin Lyase and Pectinase Sequences. Biochem, (Moscow), 74(9), 1049-1055. https://doi.org/10.1134/S0006297909090144 YODER, M. D., KEEN, N. T., JURNAK, F. (1993). New domain motif: the structure of pectate lyase C, a secreted plant virulence factor. Science, 260, 1503 1507.

ZUCKER, M., HANKIN L., SANDS. D. (1972). Factors governing pectatelyase synthesis in soft rot and non soft rot bacteria. Physiol Plant Pathol, 2, 59-67. https://doi.org/10.1016/0048-4059(72)90048-3 